This paper has been peer reviewed and accepted for publication in the Geological Society of London Special Publication on Straits and Seaways (Editors Valentina Rossi, Sergio G. Longhitano, Cornel Olariu, Francesco Chiocci). The paper is not yet published and does not have a DOI, but will soon.

Authors: Rebecca J. Dorsey ${ }^{1}$, Juan Carlos Braga ${ }^{2}$, Kevin Gardner ${ }^{1}$, Kristin McDougall ${ }^{3}$, Brennan O'Connell ${ }^{4}$

1. Dept. of Earth Sciences, University of Oregon, Eugene, OR, 97403, United States

2. Departamento de Estratigrafía y Paleontología, Universidad de Granada, Granada, Spain

3. U. S. Geological Survey, 2255 N. Gemini Dr., Flagstaff, AZ, 86001, United States

4. School of Earth Sciences, University of Melbourne, Parkvlle, Victoria 3051, Australia

Dr. Rebecca Dorsey

Professor of Earth Sciences

University of Oregon

rdorsey@uoregon.edu

@rjddorsey 


\title{
Early Pliocene Marine Transgression into the Lower Colorado River Valley, Southwestern USA, by Re-Flooding of a Former Tidal Strait
}

\author{
Rebecca J. Dorsey ${ }^{1}$, Juan Carlos Braga ${ }^{2}$, Kevin Gardner ${ }^{1}$, Kristin McDougall ${ }^{3}$, Brennan O'Connell ${ }^{4}$ \\ 1. Dept. of Earth Sciences, University of Oregon, Eugene, OR, 97403, United States \\ 2. Departamento de Estratigrafía y Paleontología, Universidad de Granada, Granada, Spain \\ 3. U. S. Geological Survey, 2255 N. Gemini Dr., Flagstaff, AZ, 86001, United States \\ 4. School of Earth Sciences, University of Melbourne, Parkville, Victoria 3051, Australia \\ September 27, 2021 - In Press:

\section{Special Publication on Straits and Seaways (Geological Society of London)}

\begin{abstract}
Marine straits and seaways are known to host a wide range of sedimentary processes and products, but the role of marine connections in the development of large river systems remains little studied. This study explores a hypothesis that shallow marine waters flooded the lower Colorado River valley at $\sim 5 \mathrm{Ma}$ along a fault-controlled former tidal straight, soon after the river was first integrated to the northern Gulf of California. The upper bioclastic member of the southern Bouse Formation provides a critical test of this hypothesis. The upper bioclastic member contains wave ripple-laminated bioclastic grainstone with minor red mudstone, pebbly grainstone with HCS-like stratification and symmetrical gravelly ripples, and calcareous-matrix conglomerate. Fossils include upward-branching segmented coralline-like red algae with no known modern relatives but confirmed as marine calcareous algae, echinoid spines, barnacles, shallow marine foraminifers, clams, and serpulid worm tubes. These results provide evidence for deposition in a shallow marine bay or estuary seaward of the transgressive backstepping Colorado River delta. Tsunamis generated by seismic and meteorologic sources likely produced the HCS-like and waveripple cross-bedding in poorly-sorted gravelly grainstone. Marine waters inundated a former tidal strait within a fault-bounded tectonic lowland that connected the lower Colorado River to the Gulf of California. Delta backstepping and transgression resulted from a decrease in sediment output due to sediment trapping in upstream basins and relative sea-level rise produced by regional tectonic subsidence.
\end{abstract}

Editors: Valentina Rossi, Sergio G. Longhitano, Cornel Olariu, Francesco Chiocci

\section{Introduction}

A growing body of literature shows that marine straits and seaways host a wide range of sedimentary processes, environments, and depositional products (Longhitano, 2013; Longhitano et al., 2014; Rossi et al., 2017; Longhitano and Steel, 2017; Telesca et al., 2020; de Weger et al., 2020; Longhitano et al., 2021). Little is known, however, about the processes by which fault-controlled marine connections influence the initiation and early development of large river systems. Faulting, subsidence and sedimentation clearly control the evolution of rivers in rift settings (e.g., Leeder and Gawthorpe, 1987; Peters and Balen, 2007; Repasch et al 2017; Skotnicki et al., 2021), but the role that tidal straits play in connecting a large river to the ocean during emergence and organization of the fluvial system remains little studied. The upper Miocene to lower Pliocene Bouse Formation in the southwest USA (Fig. 1) preserves a record of initiation and early evolution of the lower Colorado River within a diffuse transtensional plate-boundary fault system (Buising, 1990; House et al., 2008; Pearthree and House, 2014; Dorsey et al., 2021a), offering unique insights into this question. 
Recent studies show that the basal carbonate member of the southern Bouse Formation accumulated in a complex fault-controlled tidal strait (Fig. 2; O'Connell et al., 2017, 2021; Gardner and Dorsey, 2021; Dorsey et al., 2021a) followed by deposition of fluvial channel sands and floodplain fines in the earliest through-flowing Colorado River. Existing evidence indicates that the lower reaches of the valley were subsequently re-flooded by a marine transgression that led to deposition of the upper bioclastic member of the southern Bouse Formation at $\sim 5 \mathrm{Ma}$, followed by resumption of sediment discharge and final establishment of the modern Colorado River system (Dorsey et al., 2018). This sequence of events is important for understanding how tectonically controlled marine connections influenced the initiation and early development of the lower Colorado River, but the processes and chronology of evolving environments are currently debated (Gootee et al., 2019; Crow et al., 2021; Dorsey et al., 2021b). This study was undertaken to test the marine reflooding hypothesis through integration of stratigraphic, sedimentologic, and paleontologic data from the upper bioclastic member of the Bouse Formation in the lower Colorado River valley (Figs. 2, 3).

\section{Geologic and Stratigraphic Background}

\section{Overview}

The Bouse Formation is a regionally extensive thin sequence of upper Miocene to lower Pliocene interbedded carbonate and siliciclastic deposits preserved in surface exposures and subsurface basins along nearly $300 \mathrm{~km}$ of the lower Colorado River valley (i.e. south of Las Vegas; Fig. 1; Metzger, 1968; Buising, 1990; House et al., 2008; Dorsey et al., 2018). Sedimentary facies are well exposed in eroded walls of desert washes and canyons south of Blythe, California, where they overlie older Miocene volcanic rocks and conglomerate (Fig. 2; Sherrod and Tosdal, 1991; Richard, 1993). The Bouse Formation includes a thin, laterally extensive basal carbonate member overlain by a siliciclastic member that represents the oldest deposits of the early Colorado River (Dorsey et al., 2018). The siliciclastic member thickens to $>200 \mathrm{~m}$ beneath the modern Colorado River floodplain (Metzger et al., 1973; Cassidy et al., 2018; Crow et al., 2019; Cohen et al., 2019) and pinches out to zero thickness at the basin margins (Figs. 3, 4).

The upper bioclastic member of the Bouse Formation, the focus of this study, is a thin (2-10 m) unit of mixed (sensu Chiarella and Longhitano, 2012; Chiarella et al., 2017) bioclastic and locally-derived siliciclastic sand and gravel. It unconformably overlies gently dipping strata and growth structures of the two older members and is conformably overlain by younger alluvial-fan gravel (Tfg2). The upper bioclastic member and Tfg2 define a unit known as "Trigo sediments" (Gootee et al., 2016a, 2016b, 2019), which are overlain and inset by Colorado River sands and gravels of the Pliocene Bullhead Alluvium (Howard et al., 2015). The upper bioclastic member is therefore bracketed in time between two distinct packages of the oldest fluvial deposits of the early Colorado River. This unit is not recognized north of the town of Palo Verde and to date has only been documented from well mapped exposures of the Bouse Formation south of Palo Verde and north of the Highway 78 Pass (Fig. 2). A previously published geologic map shows the distribution of Bouse Formation members and section localities in a portion of the southeast Palo Verde Mountains (Fig. 5; Gardner, 2019), and a stratigraphic panel reveals the stratal architecture of a basinmargin growth monocline that controlled basinward tilting and subsidence in a broad transtensional sag basin during deposition of the Bouse Formation (Fig. 6; Dorsey et al., 2021a).

\section{Summary of Depositional Models}

Previous studies have proposed contrasting interpretations for depositional environments of the Bouse Formation. Based on the widespread occurrence of marine foraminifers, barnacles, ostracods and mollusks, most paleontologic studies suggest that the basal carbonate of the southern Bouse Formation (south of Parker, Ariz.; Fig. 1) accumulated in a restricted marine embayment at the north end of the paleo-Gulf of California (Metzger, 1968; Smith, 1970; Metzger et al., 1973; Buising, 1990; McDougall, 
2008; McDougall and Miranda-Martinez, 2014). The marine interpretation is further supported by studies of sedimentary structures, facies associations, carbonate cement fabrics, and trace fossils that record deposition in marine tidal to supratidal flats and subtidal dune fields within and around the margins of a fault-controlled tidal strait (Fig. 2B; O'Connell et al., 2017, 2021; Gardner and Dorsey, 2021). An alternative hypothesis based on $\mathrm{Sr}, \mathrm{O}$, and $\mathrm{C}$ isotopes postulates that the southern Bouse Formation formed in a large inland lake isolated from the ocean (Spencer and Patchett, 1997; Poulson and John, 2003; Roskowski et al., 2010; Spencer et al., 2008, 2013; Bright et al., 2016). In this model, the upper bioclastic member is interpreted to represent an offlap sequence of locally-sourced clastic sediments in which the bioclastic component was derived entirely from erosional reworking of the basal carbonate member (Gootee et al., 2016a, 2019). However, geochemical modeling shows that Sr-isotope ratios recorded in the Bouse basal carbonate can be produced by mixing of Colorado River water, radiogenic spring water and seawater (Crossey et al., 2015), highlighting the non-uniqueness of Sr-based interpretations. Other studies show that carbon isotopic ratios increase southward toward seawater values along the lower Colorado River valley (Poulson and John, 2003), and $\mathrm{O}$ and $\mathrm{C}$ isotopes display linear covariation overlapping with seawater (Roskowski et al., 2010; Crossey et al., 2015) in a trend commonly produced by mixing of river and ocean waters in marine estuaries (e.g., Ingram et al., 1996). Bright et al. (2018) proposed a hybrid model in which the southern Bouse Formation formed in a brackish coastal lake that was connected to the ocean through a narrow marine connection, suggesting a path forward to reconcile disparate interpretations.

Based on the widespread occurrence of tidal sedimentary structures and facies associations, lowdiversity marine fauna, diminutive marine burrows, and intertidal lime muds lacking evaporites, O'Connell et al. (2021) concluded that the basal carbonate member of the Bouse Formation southeast of Cibola, Arizona (Fig. 2), formed in brackish water created by mixing of freshwater and seawater in a marginalmarine tidal environment. These results show that large volumes of fresh water were delivered to the basin prior to arrival of the Colorado River, and that the basal carbonate member therefore records a humid paleoclimate with high annual precipitation (O'Connell et al., 2021). The marine tidal strait model (Fig. 2B; Gardner and Dorsey, 2021) integrates results from prior studies of micropaleontology (McDougall, 2008; McDougall and Miranda-Martinez, 2014; Dorsey et al., 2018), Sr, O, and C isotopes (Spencer and Patchett, 1997; Poulson and John, 2003; Roskowski et al., 2010; Crossey et al., 2015; Bright et al., 2016, 2018), and process sedimentology (O'Connell et al., 2017, 2021; Gardner and Dorsey, 2021). It thus reconciles incompatible interpretations and provides a critical framework for interpretation of the upper bioclastic member (this study). Importantly, northern exposures of the Bouse basal carbonate member (north of Parker, Ariz., Fig. 1) contain no marine fossils, bioclastic facies, or tidal sedimentary structures, and are widely agreed to have formed in a chain of lakes (House et al., 2008; Pearthree and House, 2014; Bright et al., 2018). Thus northern and southern exposures of the basal carbonate member display fundamental differences in paleontology, sedimentology, and depositional paleoenvironments, though both regions preserve evidence for voluminous input of freshwater during Bouse deposition.

The siliciclastic member of the southern Bouse Formation consists of three interbedded facies that coarsen up section (Fig. 3), from oldest to youngest: (1) a thin unit (1-5 m) of laminated green claystone with marine foraminifers (possibly reworked from underlying carbonate) and nonmarine ostracodes (Bright et al., 2016, 2018; Dorsey et al., 2018); (2) interbedded red mudstone and siltstone with weakly developed paleosols that record deposition in a low-energy prograding delta, with total thickness from 2-15 m in surface exposures to 10's of meters in subsurface wells (Metzger, 1968; Metzger et al., 1973; Buising, 1990); and (3) thick, multistorey trough cross-bedded quartz-rich sandstone that records deposition by migrating bars and bedforms in channels of the earliest through-flowing Colorado River (Dorsey et al., 2018). The total thickness of the siliciclastic member ranges from $>200 \mathrm{~m}$ beneath the floodplain of the modern Colorado River (Metzger et al., 1973) to 120 $\mathrm{m}$ in a dipping section exposed in the western Trigo Mountains (Dorsey et al., 2021a), to 0-20 m in places where systematic stratal wedge geometries record syn-depositional tilting and pinch-out of the siliciclastic member at structurally 
controlled basin margins (Dorsey et al., 2021a). The upper bioclastic member (focus of this study) rests unconformably on both the basal carbonate and siliciclastic members (Figs. 3, 4), as described below.

Age of the Bouse Formation

The age of the Bouse Formation is constrained by published biostratigraphic and radiometric data. Based on the presence of planktonic foraminifers Streptochilus latus and Globorotalia lenguaensis in the western Trigo Mountains (Fig. 2), the basal carbonate member is assigned an age of $\sim 6.1-5.3 \mathrm{Ma}$ (McDougall and Miranda-Martínez, 2014; Miranda-Martínez et al., 2017). This age is seemingly in disagreement with presence of the 4.8-Ma Lawlor Tuff interbedded with Bouse carbonate near Buzzards Peak (Fig. 2; Sarna-Wojcicki et al., 2011). This apparent contradiction is resolved by assigning the finegrained carbonate at Buzzards Peak to the Bouse upper bioclastic member, which overlies a regional unconformity and represents a wide range of depositional energies and paleoenvironments (Dorsey et al., 2018; this study). The Bouse basal carbonate is overlain by green claystone of the siliciclastic member along an abrupt contact (Fig. 3) that records first arrival of Colorado River water and sediment at $~ 5.4-5.3$ Ma (McDougall and Miranda-Martínez, 2014; Miranda-Martínez et al., 2017; Dorsey et al., 2018). This chronology is consistent with delivery of Colorado River sand to the Salton Trough starting 5.3 Ma as determined from biostratigraphy, paleomagnetism, and U-Pb dating of interbedded tuffs (Dorsey et al., 2007, 2011; Miranda-Martínez, 2019). U-Pb dating of detrital zircon (Cloos, 2014) and ${ }^{40} \mathrm{Ar} /{ }^{39} \mathrm{Ar}$ dating of detrital sanidine (Crow et al., 2021) suggest a somewhat younger age ( 4.6-4.8 Ma) for birth of the river and first arrival of Colorado River sand in the Salton Trough. This suggestion remains speculative in light of incomplete datasets and conflicting interpretations (e.g., Dorsey et al., 2021b). Regardless of these complexities, existing uncertainty over the age of the Colorado River does not affect the data, conclusions, or significance of this study.

\section{Upper Bioclastic Member of the Bouse Formation}

\section{Basal Unconformity}

The contact at the base of the upper bioclastic member in the study area is a sharp, erosional unconformity (sequence boundary) that displays quasi-planar geometry at the basin scale (Fig. 4). Around the margins of the southern Blythe basin south of Palo Verde (Fig. 2), where the older siliciclastic member is absent due to non-deposition or erosion, the upper bioclastic member rests directly on fine-grained marl of the basal carbonate member (Figs. 3, 4, 7). Vertical exposures reveal a laterally continuous zone of karst fissures and weathering, which overprints and partially obscures original bedding up to 2 $\mathrm{m}$ directly below the contact (Fig. 7A). The concentration of fissures and degree of overprinting typically increase up-section through this interval. In some exposures the unconformity displays a shallow channel geometry incised into marl of the basal carbonate member and filled with lenticular calcareous-matrix conglomerate (Fig. 7B). In other places, the contact is marked by a $\sim 20 \mathrm{~cm}$-thick silica-cemented carbonate-matrix rudstone containing clasts reworked from marl of the basal carbonate (Fig. 7C).

At localities closer to the basin center where stratal thickness and completeness increase, the upper bioclastic member rests in sharp erosional contact on the siliciclastic member of the Bouse Formation (Figs. 3, 4). One locality in the southeast Palo Verde Mountains (section KG10; Fig. 6, 7D) reveals tidal flat facies of the basal carbonate member overlain by $\sim 4 \mathrm{~m}$ of fine-grained claystone and mudstone of the siliciclastic member, which in turn is overlain along a sharp planar contact by thin-bedded sandy grainstone of the upper bioclastic member. In another example (section KG12; Fig. 8, 9A), bioclastic sandy grainstone rests in erosional contact on quartz-rich cross-bedded Colorado River sandstone of the siliciclastic member. At every location where this unconformity has been observed, it is a sharp erosional sequence boundary with no interbedding or interfingering of deposits below and above the boundary. 


\section{Physical Sedimentology}

The upper bioclastic member of the Bouse Formation typically is $~ 2$ to $10 \mathrm{~m}$ thick with total thickness locally increasing to $12 \mathrm{~m}$ near a basin-bounding fault in the western Trigo Mountains (O'Connell, 2016; Dorsey et al., 2021a). This unit contains a diverse assemblage of mixed bioclastic-siliciclastic lithofacies (Figs. 9, 10) that are divided into three main facies associations: (FA1) carbonate-rich sandy grainstone locally with interbedded red mudstone; (FA2) pebbly grainstone with distinctive gravelly wave-formed ripple cross-bedding; and (FA3) calcareous-matrix conglomerate. Bioclasts in all facies are primarily fragments of barnacles, clams, gastropods, and upward-branching coralline-like calcareous algae; significant secondary components include foraminifers, echinoids, serpulids, Chara, and ostracods. Siliciclastic sand and gravel are mixed with bioclasts in varying relative percent (e.g., Chiarella and Longhitano, 2012; Chiarella et al., 2017). At some localities the facies associations are arranged with no clear vertical trend (e.g., Fig 7A, 7B), and other sections display systematic coarsening-up from carbonaterich grainstone (FA1) to pebbly grainstone (FA2) to calcareous-matrix conglomerate (FA3) conformably overlain by younger alluvial fan gravel (Tfg2) (Fig. 8). In this study the terms "mud", "sand" and "pebble" refer to siliciclastic particles. Coarse sand and gravel are composed of locally derived Tertiary volcanic rocks and subordinate pre-Tertiary plutonic and metamorphic rocks, whereas siliciclastic mud and quartzrich fine sand are sourced almost exclusively from the Colorado River (Buising, 1990; Dorsey et al., 2018).

Facies Association 1 (FA1) consists of thin-bedded sandy bioclastic grainstone having a bioclastic/siliciclastic ratio >> 1 (b/s ratio of Chiarella and Longhitano, 2012), with abundant horizontal to wave-ripple stratification and minor thin interbeds of siliciclastic red mudstone. Isolated pebble clasts on stratification surfaces define a poorly sorted variant that generally lacks mudstone (Figs. 8, 9A). Well sorted fine-grained grainstone displays abundant horizontal to small-scale symmetrical ripple crossstratification with wavelength $\sim 5-20 \mathrm{~cm}$, often alternating with thin red mudstone beds that define segregated and sorted mud drapes (Fig. 9B, 9C). Red mudstone beds typically contain salt-lined desiccation cracks with greenish mottling, sometimes with small root casts and soil ped structures. FA1 includes coarse-grained carbonate coquina with flat-based symmetrical wave-formed ripple crossbedding interbedded with relict-stratified sandy grainstone reworked by large burrows resembling Thalassinoides (Fig. 9D). This facies association also includes intervals of very thin-bedded, well sorted planar to wavy-bedded, regularly alternating carbonate-rich and sand-rich layers (Fig. 9E). Clam shells in barnacle grainstone and shell hash typically are heavily encrusted by small barnacles which are in turn pervasively coated with a thin calcareous algal crust (Fig. 9F).

Facies Association 2 (FA2) contains subequal proportions of bioclastic and siliciclastic detritus $(b / s$ ratio 1) consisting of poorly sorted pebbly grainstone with distinctive symmetrical ripple cross-bedding that we identify as gravelly wave-formed ripples based on similarity to published examples (e.g., Leckie and Walker, 1982; Hirschaut and Dingler, 1982; Cheel and Leckie, 1992). Symmetrical cross-bedding typically displays a flat to broadly concave-up basal surface and symmetrical upper bounding surface, with two variants defined by: (i) sharp symmetrical chevron cap superposed on internal cross-strata (Fig. 10A), and (ii) rounded convex upper surface with younger strata onlapping and thinning over the top (Fig. 10B). Ripple wavelengths average $~ 0.5-1.5 \mathrm{~m}$ and ripple heights are ca. $10-20 \mathrm{~cm}$. Some exposures reveal gravelly wave-formed ripple cross-bed sets and HCS-like stratification nested in a complex vertical stacking pattern with ripple wavelengths increasing up-section from $\sim 0.25 \mathrm{~m}$ to $\sim 2.5 \mathrm{~m}$ (Fig. 11).

Facies Association 3 (FA3) consists of calcareous-matrix conglomerate ( $b / s$ ratio $<1$ to $<<1)$ with a wide range of sorting and stratification styles. One variant consists of poorly sorted conglomerate with long-wavelength, low-amplitude mounded cross-bedding that resembles hummocky and swaley crossstratification (HCS-like and SCS-like) (Fig. 10C). Other examples include horizontally bedded, unconfined to channelized poorly sorted matrix-rich conglomerate with matrix-support texture and unoriented to weakly imbricated pebble and cobble clasts (Fig. 10D). A third type consists of relatively well-sorted, 
carbonate-matrix-poor clast-supported pebble conglomerate with well-rounded and imbricated pebble clasts (Fig. 10E). This variant is observed both interbedded in the middle of the upper bioclastic member and in the conformable stratigraphic transition to overlying alluvial fan gravel (Tfg2). At one locality (PVM4, Fig. 5), cross-bedded cobble to small boulder conglomerate contains imbricated clasts indicating transport to the ESE, away from the Palo Verde Mountains, similar to the dip direction of conglomerate cross-bed foresets that display primary dips of $\sim 15-20^{\circ}$ (Fig. 10F). At this locality, the conglomerate (FA3) conformably overlies an interval of well-bedded 10 to $30 \mathrm{~cm}$-thick, sharp-based normally graded beds that grade up from pebbly grainstone to planar and trough cross-stratified sandy grainstone with locally imbricated clasts and clast clusters (Fig. 10F).

\section{Paleontology}

\section{Coralline-Like Calcareous Red Algae}

A unique aspect of the upper bioclastic member is the common occurrence of a unique form of branching calcareous red algae in all facies associations (Fig. 12). The algae are not observed in the basal carbonate member and are restricted to the upper bioclastic member of the southern Bouse Formation. The enigmatic fossils are geniculate (segmented), upward-branching, coralline-like red algae with no known close modern relatives (this supersedes Halimeda of Dorsey et al., 2018). In outcrop exposures the algae are rarely observed in life position on conglomerate clasts buried in muddy-sandy matrix (Fig. 12A) or lying on their side in conglomerate matrix near the original habitat (Fig. 12B). More commonly they are preserved as broken, abraded and rounded fragments in calcareous-matrix conglomerate (Fig. 12C), pebbly grainstone, sandy grainstone, and coarse shell hash (Fig. 12D). The algae are constructed of upward-branching thalli, with branches 1-2 mm in diameter, that converge downward to an anchor point where the holdfast is missing (Figs. 12D, 12E, 12F). Larger intact specimens range in size from $\sim 5-20 \mathrm{~cm}$ long, and smaller pieces are typically mixed with matrix of pebbly grainstone and conglomerate. Fragments of the branching red algae are so common in the upper bioclastic member that they provide a useful diagnostic marker for distinguishing this unit from the basal carbonate member in the field.

The internal structure of the algae consists of sinuous branching filaments (tubes) of micritic walls with sparse cross partitions and poorly defined growth bands (Fig. 12G). Filament sections are polygonal to subcircular, and $32-63 \mu \mathrm{m}$ in diameter. The internal structure of juxtaposed space-filling filaments is characteristic of the Family Elianellaceae Granier 2016 (Granier and Dias-Brito, 2016), a name that was proposed to replace the former Family Solenoporaceae Pia 1927. Riding (2004) showed that the type species of Solenopora is not an alga but a chaetetid sponge, making Solenoporaceae an invalid family name despite its common use in the paleontological literature, which therefore had to be replaced. Fossils included in Elianellaceae are interpreted as calcified red algae from Ordovician to Miocene marine deposits (Riding, 2004). The sinuous filaments with sparse cross partitions resemble those of Pycnoporidium lobatum Yabe and Toyama 1928 from the Oxfordian (Upper Jurassic) of NW Germany (Helm et al., 2003), and "Solenopora" cayeuxiformis Leinfelder 1986 from the Upper Jurassic of Portugal (Leinfelder, 1986). They are also similar to Pycnoporidium sinuosum Johnson and Konishi 1960 from the Upper Cretaceous of Guatemala (Johnson and Konishi, 1960) and from the Albian-Cenomanian of NE Brazil (Granier et al. 2008). The internal structure also resembles that of Pycnoporidium levantinum Johnson 1964 from the Paleocene of Iraq (Johnson, 1964).

In summary, the branching algae can be named Pycnoporidium sp. and considered as a member of the family Elianellaceae, but this adds little to our knowledge since these names are applied to fossils with a sparse record separated in time, and their true relationships are not known. Despite this ambiguity, Pycnoporidium species, "Solenopora" cayeuxiformis, and the rest of Elianellacean algae (most of them described as Solenoporaceans before 2016) are always recorded in marine deposits and 
associated with marine corals, coralline red algae, and green algae (Johnson and Konishi, 1960; Johnson, 1964; Leinfelder, 1986; Riding, 2004; Granier et al. 2008; Granier and Dias-Brito, 2016).

\section{Foraminifers and Other Fossils}

We document the vertical distribution of lithofacies and benthic foraminifers in two measured sections of the upper bioclastic member in the Palo Verde Mountains (Fig. 13). Section PVM3 contains an interbedded assemblage of facies associations FA1 - FA3 that unconformably overlie marl of the basal carbonate member (Fig. 13A). Section PVM4 displays a thin basal silica-cemented rudstone at the unconformity, which is overlain by upper bioclastic member coarsening-up from FA1 to FA3 (Fig. 13B). Samples from the basal carbonate member beneath the unconformity in both sections contain a foraminiferal fauna dominated by Ammonia beccarii with moderate numbers of Rosalina columbiensis accompanied by rare Spirilina vivipara and Streptochilus latus (Fig. 13A, 13B). This assemblage suggests marine conditions and water depths of at least $50 \mathrm{~m}$, which is typical of the lower to middle part of the basal carbonate member (Dorsey et al., 2018). Samples from the upper bioclastic member, above the unconformity, are also dominated by Ammonia beccarii with few to rare Rosalina columbiensis. This younger assemblage suggests deposition in a marginal marine setting with low salinity and water depths $\leq 50 \mathrm{~m}$. The Ammonia specimens are not stained red and do not show signs of recalcification, as was observed in a previous study of the upper bioclastic member (Dorsey et al., 2018). The size of these specimens is characteristic of a low salinity water mass in which salinity is high enough to allow normal reproduction. Single specimens of Cibicides fletcheri and Elphidium clavatum found in section PVM3 suggest that salinity may have been low but close to normal marine conditions, consistent with the common occurrence of coralline-like red algae and echinoid spines (below).

In addition to foraminifers, faunal assemblages from PMV3 and PMV4 contain common to abundant ostracods, gastropods, molluscan shell fragments, and Chara (charophytes). Ostracods and gastropods are filled with siliceous material, and many gastropod shells have lost all calcareous shell material. Ostracods are intact and usually close-shelled, with both shells attached, indicating a quiet low-energy environment. The presence of Chara indicates a brackish near-coastal setting with input of fresh water. This assemblage is similar to that found in the middle (deltaic) portion of the siliciclastic member of the Bouse Formation (Dorsey et al., 2018), suggesting deposition in a saline lake or low-salinity marine environment.

Other fossil types in the upper bioclastic member are preserved as shell concentrations on bedding planes (Fig. 14A). Barnacles are found both as disarticulated fragments and as whole individuals in growth position encrusted on bivalve shells (Fig. 9F). Shell beds contain clam shells resembling Mulinia, locally preserved in dense concentrations and mixed with barnacles and gastropods (Fig. 14B). Clams, gastropods, ostracods, echinoid spines, and serpulid worm tubes are also present, commonly coated by carbonate crusts. Echinoid spine fragments are fairly common in sandy grainstone facies. An oblique transverse cross-section view of an echinoid spine shows the central core (medulla) filled with sparry calcite, intermediate porous layer of radial lamellae (recrystallized to micrite), and dense outer cortex (Fig. 14C). Echinoid spine fragments occur as slightly tapered broken pieces composed of secondary sparry calcite (Figs. 14D,E), rarely with the tapered tip preserved at the distal end of the spine (Fig. 14E). Thin sections reveal variously oriented cross-section views of serpulid worm tubes, commonly with foraminifers and ostracods cemented in sparry calcite inside the tubes (Fig. 14F, G).

Coralline-like calcareous red algae and other bioclasts are partially to totally coated by carbonate crusts hundreds of microns to a few mm thickness (Fig. 14H). The crusts consist of more or less concentric and partially overlapping ill-defined irregular, locally scalloped laminae, usually with poor lateral continuity. Laminae range from micritic with varying density to sparry calcite. The thickness and relative proportions of both types change among bioclasts and even within the same crust. These crusts, therefore, build a sort of poorly developed oncoids (Flugel, 2010) with a bioclastic nucleus much larger 
than the coating. They can also be described as thin microbial crusts partially or totally enveloping bioclasts. Modern and fossil oncoids and laminated crusts on bioclasts are coated carbonate grains formed by microbial activity from fresh-water to offshore marine environments (Smith and Mason, 2006; Pederson et al., 2015; Bádenas and Aurell, 2010).

\section{Discussion}

Data and results presented above show that the upper bioclastic member of the southern Bouse Formation accumulated in a shallow marine bay that occupied a former tidal strait during regional transgression and back-stepping of the Colorado River delta up into the lower reaches of the river valley (Fig. 15). The observation that this unit overlies cross-bedded channel sands and floodplain fines of the earliest Colorado River requires a dramatic change of depositional environment in the southern Blythe basin, and shows that that shallow marine inundation into the lower valley took place after the river first ran through it. This is a critical event in the punctuated early development of the Colorado River that has received some attention (Dorsey et al., 2018) and is currently debated (Crow et al., 2021; Dorsey et al., 2021b). Below we explore the significance of the upper bioclastic member with discussion of the basal unconformity, paleoenvironmental interpretation, depositional processes, dynamics of back-stepping and retreat of the Colorado River delta, and regional tectonic controls on this unique episode of marine transgression into the lower reaches of the Colorado River valley.

\section{Basal Unconformity}

The presence of karst fissures in a zone of weathering directly beneath the sharp base of the upper bioclastic member (Fig. 7) provides evidence for subaerial exposure and dissolution of older marine carbonate deposits around the margins of the southern Blythe basin during development of a regional unconformity (e.g., Meng et al., 1997; Booler and Tucker, 2002; Chiarella and Longhitano, 2012). Exposure and erosion of previously-deposited marine and fluvial deposits resulted from a fall in relative sea level that was controlled by an unknown combination of global sea-level fall and/or tectonic uplift (e.g., Catuneanu et al., 2009). Relative sea-level fall occurred shortly after deposition of channel sands and floodplain fines (Tbs) in the earliest through-flowing Colorado River, and may have contributed to flushing of earliest Colorado River sands down-river to the Gulf of California (Dorsey et al., 2018). This lowstand event may correlate to a fall in global sea level that occurred between 5.3 and $5.2 \mathrm{Ma}$ (Miller et al., 2011), though this mechanism appears unlikely based on a newer analysis that shows irregular sea-level variations of $\leq 5 \mathrm{~m}$ magnitude during that time (Miller et al., 2020). Locally preserved rudstone lag deposits record development of a transgressive ravinement surface (Figs. 7C, 15) that is merged with the underlying subaerial unconformity, similar to examples in southern Italy where wave action during rising sea level eroded a surface mantled by lag deposits (Zecchin et al., 2019). Deposition and aggradation of shallow marine facies above the unconformity records a subsequent rise of relative sea level, production of new accommodation space, and resumption of the carbonate factory in a shallow-marine setting. The sharp base of the upper bioclastic member (Figs. 7, 9A) is therefore recognized as a flooding surface sequence boundary, which initially formed as a result of relative sea-level fall and later was reoccupied during marine transgression and ravinement due to a subsequent rise of relative sea level in the southern Blythe basin (e.g., Bhattacharya, 2011; Blum et al, 2013).

\section{Paleoenvironmental Reconstruction}

Paleontology and process sedimentology documented above provide evidence for deposition of the upper bioclastic member in a shallow marine bay or estuary in the lower reaches of the Colorado River valley. Echinoids are widely regarded as stenohaline invertebrates, and their presence in the upper bioclastic member thus requires a paleoenvironment with access to normal marine water in at least some 
sub-environments. While the majority of echinoid species inhabit normal marine waters, some species are known from habitats with salinities that may change from brackish to normal (Reid et al., 2008; Russell, 2013) and hypersaline waters with salinities up to 48 per mil, both in hypersaline supratidal flats (Persian Gulf and Suez Canal, Russell, 2013) and in relatively enclosed embayments such as the Sarfaga Bay in the northern Red Sea (Nebelsick, 1991) and the Spencer Gulf in South Australia (O'Connell et al., 2016). Therefore, the occurrence of echinoid remains is a critical record of marine to marginal marine habitats that may have included diverse and changing salinities.

Although no close modern relatives are known for the coralline-like red algae documented in this study, algae of this family are always recorded in marine deposits associated with corals, coralline red algae, and green algae. Serpulid worms are marine invertebrates with the only exception of a species known from caves in the Dinaric karst (Italy, Slovenia, Croatia and Bosnia-Hercegovina) and five additional species that inhabit brackish waters (Kupriyanova et al., 2009). The echinoids and branching red algae cannot be reworked from older deposits because they are only found in the upper bioclastic member and are never observed in the basal carbonate member. Densely packed clams resemble Mulinia coloradoensis, a brackish species that was once abundant in the modern Colorado River delta and is now nearly extinct (Kowalewski et al., 2000; Rodriguez et al., 2001). Although charophytes are known from freshwater environments, they are also common in modern coastal waters and brackish saline lagoons of the Baltic Sea, Adriatic Sea, and coastal Scotland (Blindow, 2000; Ainsley Martin et al., 2002; Zeneli and Kashta 2016, Bučas et al., 2019). The observed mixing of charophyte debris with marine fossils in bioclastic grainstone thus requires a marine setting. The co-occurrence of marine foraminifers (Elphidium, Cibicides, Rosalina, and normal-size undeformed $A$. beccarii) with echinoid spines, branching coralline-like red algae, barnacles, densely packed clam beds, and wave-formed ripples all support the conclusion that the upper bioclastic member formed in a high-energy shallow marine bay or estuary. Complex circulation and resulting local variations in salinity likely resulted from mixing of (i) hypersaline waters in shallow coastal lagoons and channels, (ii) fresh water from the Colorado River and local catchments, and (iii) normal marine waters at the restricted north end of paleo-Gulf of California (Fig. 15).

\section{Transport and Depositional Processes}

FA1. Lithofacies and paleontologic data from the upper bioclastic member are interpreted to record mixed bioclastic-siliciclastic transport, reworking, and sedimentation in a high-energy shallow marine environment. Well sorted ripple-laminated grainstone was deposited by combined wave and unidirectional currents in a nearshore setting. The common association of horizontal stratification, rhythmic thin bedding, regularly alternating carbonate-rich and sand-rich layers, symmetrical wave ripple cross-lamination, thin lenticular mudstone drapes, and salt-lined desiccation cracks (Fig. 9B, 9C) provides evidence for regular alternation of traction transport and slack-water conditions punctuated by short intervals of subaerial exposure near the margins of a shallow marine bay. Presence of red mudstone drapes on well sorted symmetrical grainstone ripples with flaser and wavy bedding geometries (Fig. 9C) suggests a tidal influence on sedimentation (e.g., Klein, 1977; Reineck and Singh, 1980; Chiarella and Longhitano, 2012). Alternatively, local water-level fluctuations and episodic drying of mud flats could have resulted from wind-forced set-up and set-down, or density-driven water circulation resulting from input of fresh water to the head of the shallow bay. Isolated pebble clasts and stringers represent lag deposits formed by reworking of thicker gravel beds originally deposited by coastal floods and debris flows. Flatbased convex-up symmetrical cross-bedding in coarse shelly coquina interbedded with heavily bioturbated sandy grainstone (Fig. 9D) records deposition in slightly deeper water by oscillatory currents in a high-energy shallow subtidal setting. The general absence of muddy matrix suggests currents were strong enough to transport resuspended mud away.

Of particular interest, minor interbedded red mudstone in FA1 (Figs. 9B,C, 13A) is identical to red mudstone with salt-lined desiccation cracks and soil peds interbedded with siltstone and fine-grained 
Colorado River sandstone of the Bouse Formation exposed on the north flank of the Riverside Mountains, $\sim 20 \mathrm{~km}$ WSW of Parker (Figs. 1, 15). The Riverside Mountains section contains thin beds of well sorted sandy bioclastic grainstone with abundant mollusk fragments and rare specimens of Batillaria californica, a small gastropod known from the basal carbonate of the Bouse Formation (Taylor, 1983). These deposits belong to a sequence of fine-grained Colorado River-derived siliciclastic facies that thicken to $\sim 200 \mathrm{~m}$ in the subsurface of the Parker area (Metzger et al., 1973; Crow et al., 2019). Based on strong similarity to the mudstone-bearing variant of FA1, and stratigraphic relations documented in this study, we suggest the fine-grained facies west of Parker (northern Riverside Mountains) represent a transgressive bayhead delta that formed in the northern Blythe basin coeval with deposition of the upper bioclastic member in the south (Fig. 15C, D, E). In this interpretation, thin red mudstone interbeds in FA1 represent the most distal fine-grained sediment of the Colorado River that likely was delivered by large river floods.

FA2. Symmetrical gravelly ripples and HCS-like structures in the upper bioclastic member (Figs. 10, 11) formed by deposition of mixed bioclastic and siliciclastic detritus from oscillatory and combined-flow currents in a high-energy shallow-marine bay. The scale, grain size, stratification style, and geometry of coarse-grained ripples observed in this study strongly resemble gravelly wave-formed ripples documented from storm deposits in modern and ancient marine shelf settings (Leckie and Walker, 1982; Hirschaut and Dingler, 1982; Leithold and Bourgeois 1984; DeCelles, 1987; Leckie, 1988; Cheel and Leckie, 1992), and are strikingly similar to modern gravelly wave ripples formed in $\sim 10 \mathrm{~m}$ water depth off Monastery Beach in central California (Hirschaut and Dingler, 1982, their Figs. 6, 7). However, the above-cited examples all formed in open marine-shelf settings that were (or are) exposed to large storms with a long ocean fetch. In contrast, the upper bioclastic member accumulated in a narrow irregular bay within the lower Colorado River valley at the north end of the paleo-Gulf of California (Fig. 2, 15C). This setting lacks the long fetch and exposure to open ocean currents that are considered necessary to create storm conditions suitable for generation of gravelly wave-formed ripples. Moreover, the observed low-relief long-wavelength HCSlike and SCS-like structures occur in poorly-sorted gravel-rich facies (Figs. 10C; 11), unlike well-sorted sand-dominated textures observed in HCS and wave-formed ripples documented from open marine shoreface and shelf environments (e.g., Dumas et al; 2005; Morsilli \& Pomar, 2012).

Tsunamis, on the other hand, generate a diverse suite of erosional and transport processes that can explain most sedimentary structures observed in the upper bioclastic member. In addition to earthquakes, atmospheric phenomena such as gravity waves, pressure jumps, frontal passages and rain squalls are a common source of ocean waves in the tsunami frequency band (wave period $\sim 20$ minutes to 2 hours) known as meteorological tsunamis or "meteotsunamis" (Monserrat et al., 2006). Destructive waves produced by meteotsunamis have been documented from restricted marine bays around the world, including the Persian Gulf (Heidarzadeh et al., 2020), Nagasaki Bay in Japan (Vilibić et al., 2021), small bays in the Balearic Islands, Mediterranean Sea (Rabinovich, 2019; Jansà and Ramis, 2020), eastern coastal region of the Adriatic Sea (Pattiaratchi and Wijeratne, 2015), and the Gulf of Finland (Pellikka et al., 2020). Tsunamis generated by either source produce strong uni- and bi-directional currents that can erode and entrain a wide range of grain sizes, rapidly transport alluvial debris and coastal organic remains offshore, and deposit poorly sorted gravelly sand with displaced fossil fragments in shallow marine bays (Dawson and Stewart, 2007; Fujiwara and Kamataki, 2008; Fujiwara, 2021; Costa et al., 2021; Shiki et al., 2021). Despite the high preservation potential of offshore tsunami deposits, they are difficult to observe in modern settings and thus are sparsely recorded and poorly understood. Nonetheless, recent studies document shallow marine deposits formed by tsunami run-up and backwash, debris flows reworked by coeval waves undergoing local resonance and amplification, and supercritical fast shallow flows (Froude number $\geq 1$ ) that create antidunes with low-relief HCS-like and SCS-like structures in poorly sorted gravelly sand (e.g., Massari \& D’Alessandro, 2000; Fujino et al., 2006; Fujiwara, 2021; Costa et al., 2021; Shiki et al., 2021). We therefore suggest that gravelly symmetrical ripples and long-wavelength HCS-like 
stratification in the upper bioclastic member record deposition from seismic and meteorological tsunamis within a restricted, fault-bounded shallow marine bay (Fig. 15C).

FA3. Calcareous-matrix conglomerate of FA3 records increased input of gravel to the shallow marine bay represented by deposits of FA1 and FA2. Poorly sorted conglomerate was deposited by subaqueous debris flows sourced from nearby local catchments. Well sorted and imbricated pebble conglomerate formed by reworking in high-energy upper shoreface to beach environments. Cross-bedded conglomerate with imbricated clasts (Fig. 10F) is interpreted to record rapid sedimentation in gravelly channel-mouth bars and locally developed small Gilbert-type fan delta lobes that prograded over an upper shoreface slope represented by the underlying mass-flow deposits (e.g., Kleinspehn et al., 1984; Sohn and Son, 2004; Blair and McPherson, 2008). The general absence of Gilbert deltas, and abundance of reworked stratified gravel deposits interbedded with shallow marine facies, suggests deposition in shoal-water fan deltas (sensu Postma, 1990) that prograded from alluvial fans at the margins of the marine embayment.

In summary, an idealized depositional sequence for the upper bioclastic member consists of: (i) marine flooding and ravinement of a previously-formed subaerial unconformity during a rise in relative sea level, (ii) FA1: shallow-marine deposition of mixed bioclastic-siliciclastic sands south of the transgressive retreating Colorado River delta; (iii) FA2: moderate deepening and deposition of debris flows reworked by oscillatory to unidirectional rip currents associated with seismic and meteorological tsunamis; (iv) FA3: shallowing due to progradation of shoal-water fan deltas into the marine embayment; and (v) final conformable transition to locally sourced gravelly alluvial fans (Tfg2) (Figs. 3, 4).

\section{Regional Transgression and Back-Stepping of the Colorado River Delta}

An important finding of this study is that bioclastic grainstone and pebbly grainstone of the upper bioclastic member overlie a basal transgressive ravinement surface with only local preservation of thin mudstone interbeds that represent the most distal siliciclastic component of the retreating delta (Figs. 7A-C, 9B-C). This architecture is unlike other examples of backstepping bayhead deltas where riverderived pro-delta muds and silts overlie older sand-rich delta-plain deposits, thus defining a preserved transgressive systems tract located seaward of the retreating delta front (Aschoff et al., 2018; Simms et al, 2018; Evans et al., 2019; Rossi et al., 2021). In contrast to these published examples, the stratal architecture of the Bouse Formation in the southern Blythe basin (Figs. 3, 4, 15D,E) shows that early Pliocene transgressive retreat of the Colorado River delta took place during nearly complete shut-down of river sediment output to the ocean during a rapid rise in relative sea level. This finding is consistent with prior conclusions based on correlation of the upper bioclastic member to a regional marine claystone that overlies sand-rich channel-fill turbidites in the Salton Trough (Dorsey et al., 2018). While the absolute age of those deposits remains uncertain (Crow et al, 2021; Dorsey et al., 2021b), the relative sequence of events documented in this study is unambiguous.

Sediment discharge during deposition of the older siliciclastic member, prior to the decrease, has been estimated at 3-10 Mt/yr (Dorsey et al., 2018). This rate is similar to sediment discharge measured in large modern rivers such as the Rio Grande, Waipoa, Sao Francisco, Niger, Columbia, and Saint Lawrence rivers (Milliman and Meade, 1983; Milliman and Syvitski, 1992), and is much less than the geologic and modern pre-dam values of 150-200 Mt/yr calculated for the Colorado River (Dorsey and Lazear, 2013). The early Pliocene sediment flux corresponds to erosion rates of 4-20 m/Myr on the Colorado Plateau, which is similar to ${ }^{10} \mathrm{Be}$-based paleo-erosion rates of $10-40 \mathrm{~m} /$ Myr for the early Pliocene Colorado River (Matmon et al., 2012) and less than long-term erosion rates of 100-300 m/Myr (Darling et al., 2012; Aslan et al., 2019). The low sediment flux of the earliest Colorado River during deposition of the siliciclastic member (Tbs) provides a clue to understanding the shutdown at $5 \mathrm{Ma}$, in that a relatively slow flux is easier to temporarily stop than the much larger flux rates calculated over long-term to modern timescales (Dorsey and Lazear, 2013). 
Source-to-sink and sediment-routing models show that river sediment flux to the oceans, and the corresponding fate of river deltas, is governed by two main factors: (1) the volumetric rate of sediment delivery to the delta, which is controlled by erosion rate in upland source areas plus efficiency with which sediment is transferred through a river channel network to the shoreline; and (2) changes of relative sea level in the receiving basin due to changes in global sea level and/or variations in tectonic subsidence rate (Muto and Steel, 1997; Paola, 2000; Paola et al., 2001; Castelltort and Van Den Driessche, 2003; Michael et al., 2013; Romans et al., 2016; Allen, 2017). In particular, the magnitude of sediment flux arriving at the head of a delta depends on a range of processes that govern spatial and temporal variations in sediment discharge (Qs) along the fluvial transfer sub-system (Castelltort and Van Den Driessche, 2003). These processes include feedbacks in response to changes in Qs arriving from upstream, and basin subsidence along the fluvial sediment routing system which can sequester sediment and reduce Qs that gets transferred to farther downstream reaches (Michael et al., 2013; Romans et al., 2016; Allen, 2017).

Building on these concepts, we propose that backstepping and retreat of the Colorado River delta at $\sim 5 \mathrm{Ma}$ was driven by two closely related processes: (1) a decrease in sediment flux that resulted from increased rates of fault-controlled subsidence and sediment trapping in the Parker and Needles areas (Fig. 15); and (2) tectonic subsidence that caused a rise in relative sea level recorded in the transgressive ravinement surface at the base of the upper bioclastic member. A $3 \mathrm{~km}$-deep basin beneath the Mohave Valley near Needles, CA (Saltus and Jachens, 1995), could have stored Colorado River sand during a period of rapid subsidence and accumulation, though the age of subsurface deposits is not well known. The Stateline fault and Bill Williams River fault zone were an active dextral strike-slip fault system that likely controlled subsidence in a series of transtensional sag basins during deposition of the Bouse Formation from Needles to the southern Blythe basin (Bennett et al., 2016; Dorsey et al., 2021a). These faults were kinematically linked to the northwest along strike to the Furnace Creek fault zone near Death Valley (Fig. 1), where several studies document a major pulse of strike-slip and normal fault activity that produced rapid subsidence in fault-bounded basins and active uplift of adjacent footwall blocks starting 5-6 Ma. This phase of transtensional deformation and basin subsidence is recorded in structural evolution of the Furnace Creek fault zone (Fridrich and Thompson, 2011), low-temperature thermochronology of exhumed footwall rocks in the Black Mountains (Sizemore et al., 2019), and detailed chronology of the syn-tectonic Copper Canyon Formation (Nyborg, 2011). While the timing of early Pliocene faulting in the Death Valley area requires more work, this 5-6 Ma pulse of transtensional faulting and subsidence provides a plausible mechanism to trap sediment in fault-controlled basins upstream of the retreating Colorado River delta at ca. $5 \mathrm{Ma}$ (Fig. 15). Transgression was amplified by a regional rise in relative sea level that, because global sea level was not changing significantly during that time (Miller et al., 2020), likely resulted from fault-controlled subsidence along the river corridor south of Parker.

\section{Role of Syn-Depositional Faults and Tectonic Subsidence}

In order for transgressive backstepping of the early Pliocene delta to occur, the Colorado River needed a retreat route, a lowland pathway along which the delta could migrate some $100 \mathrm{~km}$ back up into the lower reaches of the valley near Parker (Fig. 15C). Large-scale retreat is often not expected for a continental-scale river once it is integrated to the ocean, but the data and observations presented above contain compelling evidence for this event. Fault-controlled subsidence and trapping of sediment in northern (up-river) basins, combined with relative sea-level rise in the south, provides a plausible mechanism to drive delta backstepping. In addition, a connection to the ocean was needed to create and maintain a path for retreat of the delta from the Salton Trough upstream to the Parker area. Recent results from the southern Bouse Formation show that a fault-bounded tidal strait trended across the Chocolate Mountains during deposition of the basal carbonate member (Figs. 2B, 15A; Gardner and Dorsey, 2021), providing the necessary connection. Thus we infer that tectonic subsidence on pre- to syn-depositional faults exerted a fundamental control on the location and geometry of the paleo-tidal strait, as well as the 
dynamic behavior of the river and delta system, during emergence and early evolution of the Colorado River.

Specifically, we postulate that fault-controlled subsidence guided initial incursion of marine water into the lower river valley during deposition of the basal carbonate member in a tectonically active tidal strait, prior to arrival of the river (Fig. 15A) (Gardner and Dorsey, 2021; O'Connell et al., 2021; Dorsey et al., 2021a). As proposed by previous workers (Dillon, 1976; Sherrod and Tosdal, 1991), the marine tidal strait then became the route of the earliest through-flowing Colorado River to the Gulf of California as the delta prograded southward during deposition of the siliciclastic member in the study area (Fig. 15B). Shortly thereafter, fault-controlled subsidence provided a path for marine reflooding and transgression back into the lower reaches of the river valley during deposition of the upper bioclastic member at $~ 5 \mathrm{Ma}$ (Fig. 15C). Finally, the river shifted to its modern path where it follows a twisted route through faulted bedrock east of the paleo-strait, entering Yuma from the east (Figs. 1, 2B, 15). The Pliocene Bullhead alluvium is documented from surface exposures and subsurface wells around Yuma, including east of Yuma (Olmsted et al 1973; Howard et al., 2015), indicating that the Colorado River had moved over to its modern course by or before the end of Bullhead deposition. These deposits accumulated during a major phase of regional river aggradation and basin filling (Howard et al., 2015), and apparently filled the southern Blythe basin soon after the end of transgressive re-flooding documented in this study. We suggest that this aggradation stage allowed the river to migrate laterally east to its modern course where the channel has since incised into bedrock. Base-level fall due to slow regional uplift in the Chocolate Mountains over the past ca. 4 Myr, combined with termination of slip on basin-bounding faults of the southern Blythe basin, has isolated small remnants of Bouse Formation near the former tidal strait and continues to drive incision of the lower Colorado River along its modern path north of Yuma.

\section{Conclusions}

Data presented in this study confirm a marine origin for the upper bioclastic member of the Bouse Formation in the southern Blythe basin, California and Arizona, USA. Sedimentary lithofacies include wellsorted bioclastic grainstone with minor interbedded red mudstone, pebbly grainstone with HCS-like stratification and gravelly symmetrical ripples, and calcareous-matrix conglomerate transitional to overlying alluvial fan gravels. Marine fossils include upward-branching coralline-like calcareous red algae, echinoid spines, barnacles, shallow marine foraminifers, marginal marine clams, serpulid worm tubes, and large burrow networks resembling Thalassinoides. These sediments were deposited by high-energy currents, likely under the influence of repeated seismic and meteorologic tsunamis, in a shallow marine bay or estuary located seaward of the transgressive backstepping Colorado River delta at ca. 5 Ma.

These results show that shallow marine waters inundated a former tidal strait in the lower Colorado River valley shortly after the river first ran through it, aided by fault-controlled tectonic subsidence that created and maintained a connection from the lower reaches of the river to the ocean. The tidal strait initially formed by transtensional faulting and subsidence during deposition of the basal carbonate member of the Bouse Formation, creating an initial connection from the Gulf of California to an inland shallow sea in the north. The same tidal strait was then occupied by the earliest Colorado River which transported sediment from the Colorado Plateau to the Gulf of California during deposition of the Bouse siliciclastic member. Continued fault-controlled subsidence maintained a narrow lowland corridor that permitted marine re-flooding, transgression, and retreat of the Colorado River delta $\sim 100 \mathrm{~km}$ back into the lower river valley after the river was first established, leading to deposition of the Bouse upper bioclastic member. Recognition of these events provides new insight into dynamic interactions among accommodation space, tectonic subsidence, sediment flux, and relative sea level that governed unsteady emergence and early evolution of the continental-scale Colorado River system.

The short-lived phase of transgression and delta backstepping likely was controlled by two related processes: (1) shut-down of sediment output as a result of fault-controlled subsidence and sediment 
trapping in the Needles and Parker areas, and (2) a rise in relative sea level that resulted from transtension and subsidence along the fluvial tectonic lowland south of Parker. A pulse of fault activity in the Death Valley region 5-6 Ma is postulated as a driver of increased fault slip rates and tectonic subsidence in the lower Colorado River valley. These findings highlight the importance of tectonic subsidence and sediment trapping as major controls on river initiation and evolution adjacent to active plate boundaries.

Acknowledgments. Research for this study was supported by grants from the National Science Foundation (EAR-1546006), Society for Sedimentary Geology, and Geological Society of America. We thank Sue Beard, Scott Bennett, Mike Darin, Steve Hasiotis, and Keith Howard for fruitful discussions. Keith Howard is thanked for introducing R. Dorsey to the Bouse Formation. Constructive thoughtful reviews by Robert Dalrymple, Dominico Chiarella, Cornel Olariu, and Scott Bennett helped improve the final version of this paper.

\section{References Cited}

Ainsley Martin, Laurence Carvalho \& Alexander J. Downie, 2002. Rare charophytes in Scotland's coastal saline lagoons, Botanical Journal of Scotland, 54, 23-35, DOI: 10.1080/037466600208685026.

Allen, P.A., 2017. Sediment routing systems: The fate of sediment from source to sink. Cambridge University Press.

Aschoff, J.L., Olariu, C. and Steel, R.J., 2018. Recognition and significance of bayhead delta deposits in the rock record: A comparison of modern and ancient systems. Sedimentology, 65(1), pp.62-95. https://doi.org/10.1111/sed.12351

Aslan, A., Karlstrom, K.E., Kirby, E., Heizler, M.T., Granger, D.E., Feathers, J.K., Hanson, P.R. and Mahan, S.A., 2019. Resolving time-space histories of Late Cenozoic bedrock incision along the Upper Colorado River, USA. Geomorphology, 347, p.106855. https://doi.org/10.1016/j.geomorph.2019.106855.

Bádenas, B., Aurell, M. (2010) Facies models of a shallow-water carbonate ramp based on distribution of non-skeletal grains (Kimmeridgian, Spain), Facies 56, 89-11. https://doi.org/10.1007/s10347-009-0199-z

Bennett, S.E.K., Darin, M.H., Dorsey, R.J., Skinner, L.A., Umhoefer, P.J., and Oskin, M.E., 2016. Animated Tectonic Reconstruction of the Lower Colorado River Region: Implications for Late Miocene to Present Deformation, in Reynolds, R.E. eds., Going LOCO: Investigations along the Lower Colorado River, p. 73-86.

Bhattacharya, J.P., 2011. Practical problems in the application of the sequence stratigraphic method and key surfaces: integrating observations from ancient fluvial-deltaic wedges with Quaternary and modelling studies. Sedimentology, 58(1), pp.120-169. https://doi.org/10.1111/i.1365-3091.2010.01205.x.

Blair, T.C. and Mcpherson, J.G., 2008. Quaternary sedimentology of the Rose Creek fan delta, Walker Lake, Nevada, USA, and implications to fan-delta facies models. Sedimentology, 55(3), pp.579-615. https://doi.org/10.1111/j.1365-3091.2007.00913.x.

Blindow, I., 2000. Distribution of Charophytes along the Swedish coast in relation to salinity and eutrophication. International Review of Hydrobiology, 85, 707-717. https://doi.org/10.1002/15222632(200011)85:5/6<707::AID-IROH707>3.0.CO;2-W

Blum, M., Martin, J., Milliken, K. and Garvin, M., 2013. Paleovalley systems: insights from Quaternary analogs and experiments. Earth-Science Reviews, 116, pp.128-169. https://doi.org/10.1016/i.earscirev.2012.09.003.

Booler, J. and Tucker, M.E., 2002. Distribution and geometry of facies and early diagenesis: the key to accommodation space variation and sequence stratigraphy: Upper Cretaceous Congost Carbonate platform, Spanish Pyrenees. Sedimentary Geology, 146(3-4), pp.225-247. https://doi.org/10.1016/S0037-0738(01)00120$\underline{8}$

Bright, J., Cohen, A.S., Dettman, D.L., Pearthree, P.A., Dorsey, R.J. and Homan, M.B., 2016. Did a catastrophic lake spillover integrate the late Miocene early Pliocene Colorado River and the Gulf of California?: Microfaunal and stable isotope evidence from Blythe Basin, California-Arizona, USA. Palaios, 31(3), pp.81-91. https://doi.org/10.2110/palo.2015.035.

Bright, J., Cohen, A.S., Dettman, D.L. and Pearthree, P.A., 2018. Freshwater plumes and brackish lakes: Integrated microfossil and $\mathrm{OC}-\mathrm{Sr}$ isotopic evidence from the late Miocene and early Pliocene Bouse Formation (California- 
Arizona) supports a lake overflow model for the integration of the lower Colorado River corridor. Geosphere, 14(4), pp.1875-1911. https://doi.org/10.1130/GES01610.1.

Bučas, M., Sinkevičienė, Z., Kataržytè, M., Vaičiūtè, D., Petkuvienè, J., Stragauskaitè, V. and Ilginė, R., 2019. How much can the occurrence and coverage of charophytes in an estuarine lagoon (Curonian Lagoon) be explained by environmental factors?. Estuarine, Coastal and Shelf Science, 216, pp.128-138. https://doi.org/10.1016/i.ecss.2018.01.017.

Buising, A.V., 1990. The Bouse Formation and bracketing units, southeastern California and western Arizona: Implications for the evolution of the Proto-Gulf of California and the lower Colorado River. Journal of Geophysical Research: Solid Earth, 95(B12), pp.20111-20132. https://doi.org/10.1029/JB095iB12p20111.

Cassidy, C. E., Crow, R., House, P. K., Thacker, J. O., Beard, L. S., Cohen, A. S., Pearthree, P. A., and Howard, K. A.: Subsurface data in the Lower Colorado River corridor and its implications for tectonic models of basin evolution within the Palo Verde and Parker Valleys. GSA Cordilleran/Rocky Mtn Sect. Mtg., Flagstaff, AZ, USA, Paper 64-28, 2018.

Castelltort, S. and Van Den Driessche, J., 2003. How plausible are high-frequency sediment supply-driven cycles in the stratigraphic record?. Sedimentary geology,157(1-2), pp.3-13. https://doi.org/10.1016/S00370738(03)00066-6.

Catuneanu, O., Abreu, V., Bhattacharya, J.P., Blum, M.D., Dalrymple, R.W., Eriksson, P.G., Fielding, C.R., Fisher, W.L., Galloway, W.E., Gibling, M.R. and Giles, K.A., 2009. Towards the standardization of sequence stratigraphy. EarthScience Reviews, 92(1-2), pp.1-33. https://doi.org/10.1016/j.earscirev.2008.10.003.

Cheel, R.J. and Leckie, D.A., 1992. Coarse-grained storm beds of the Upper Cretaceous Chungo Member (Wapiabi Formation), southern Alberta, Canada. Journal of Sedimentary Research,62(6), pp. 933-945. https://doi.org/10.1306/D4267A1E-2B26-11D7-8648000102C1865D.

Chiarella, D. and Longhitano, S.G., 2012. Distinguishing depositional environments in shallow-water mixed, biosiliciclastic deposits on the basis of the degree of heterolithic segregation (Gelasian, Southern Italy). J. Sediment. Res., 82, 969-990. https://doi.org/10.2110/jsr.2012.78.

Chiarella, D., Longhitano, S.G. and Tropeano, M., 2017. Types of mixing and heterogeneities in siliciclasticcarbonate sediments. Marine and Petroleum Geology, 88, pp.617-627. https://doi.org/10.1016/j.marpetgeo.2017.09.010.

Cloos, M.E., 2014. Detrital zircon U-Pb and (U-Th)/He geo-thermochronometry and submarine turbidite fan development in the Mio-Pliocene Gulf of California, Fish Creek-Vallecito Basin, southern California. Unpubl. M.S. thesis, University of Texas, Austin, Texas, $216 \mathrm{p}$.

Cohen, A., Cassidy, C., Crow, R., Bright, J., Crossey, L., Dorsey, R., Gootee, B., House, K., Howard, K., Karlstrom, K. and Pearthree, P., 2019. The Bouse Formation, a controversial Neogene archive of the evolving Colorado River: a scientific drilling workshop report (28 February-3 March 2019-BlueWater Resort \& Casino, Parker, AZ, USA). Scientific Drilling, 26, pp.59-67. https://doi.org/10.5194/sd-26-59-2019.

Costa, P.J.M., Feist, L., Dawson, A.G., Stewart, I., Reicherter, K. and Andrade, C., 2021. An overview on offshore tsunami deposits, in Shiki, T., Tsuji, Y., Yamazaki, T., and Nanayama, F. (Eds.) Tsunamiites (Second Edition): Features and Implications, Elsevier, Amsterdam, pp. 183-192. https://doi.org/10.1016/B978-0-12-8239391.00011-2.

Crossey, L.C., Karlstrom, K.E., Dorsey, R., Pearce, J., Wan, E., Beard, L.S., Asmerom, Y., Polyak, V., Crow, R.S., Cohen, A. and Bright, J., 2015. Importance of groundwater in propagating downward integration of the 6-5 Ma Colorado River system: Geochemistry of springs, travertines, and lacustrine carbonates of the Grand Canyon region over the past 12 Ma. Geosphere, 11(3), pp.660-682. https://doi.org/10.1130/GES01073.1.

Crow, R.S., Howard, K.A., Beard, L.S., Pearthree, P.A., House, P.K., Karlstrom, K.E., Peters, L., McIntosh, W., Cassidy, C., Felger, T.J. and Block, D., 2019. Insights into post-Miocene uplift of the western margin of the Colorado Plateau from the stratigraphic record of the lower Colorado River. Geosphere, 15(6), pp.1826-1845. https://doi.org/10.1130/GES02020.1.

Crow, R.S., Schwing, J., Karlstrom, K.E., Heizler, M., Pearthree, P.A., House, P.K., Dulin, S., Jänecke, S.U., Stelten, M. and Crossey, L.J., 2021. Redefining the age of the lower Colorado River, southwestern United States. Geology, 49 (6): 635-640. https://doi.org/10.1130/G48080.1.

Darling, A.L., Karlstrom, K.E., Granger, D.E., Aslan, A., Kirby, E., Ouimet, W.B., Lazear, G.D., Coblentz, D.D. and Cole, R.D., 2012. New incision rates along the Colorado River system based on cosmogenic burial dating of terraces: 
Implications for regional controls on Quaternary incision. Geosphere, 8(5), pp.1020-1041. https://doi.org/10.1130/GES00724.1.

Dawson, A.G. and Stewart, I., 2007. Tsunami deposits in the geological record. Sedimentary Geology, 200(3-4), pp. 166-183. https://doi.org/10.1130/G47944.1.

DeCelles, P.G., 1987. Variable preservation of middle Tertiary, coarse-grained, nearshore to outer-shelf storm deposits in southern California. Journal of Sedimentary Research, 57(2), pp.250-264. https://doi.org/10.1306/212F8AF8-2B24-11D7-8648000102C1865D.

de Weger, W., Hernández-Molina, F.J., Flecker, R., Sierro, F.J., Chiarella, D., Krijgsman, W. and Manar, M.A., 2020. Late Miocene contourite channel system reveals intermittent overflow behavior. Geology, 48(12), pp.1194-1199. https://doi.org/10.1130/G47944.1.

Dillon, J.T., 1976. Geology of the Chocolate and Cargo Muchacho Mountains, southeasternmost California. University of California (Doctoral Dissertation). 575 pp., Univ. of Calif., Santa Barbara.

Dorsey, R.J., Fluette, A., McDougall, K.A., Housen, B.A., Janecke, S.U., Axen, G.J., and Shirvell, C.R., 2007. Chronology of Miocene-Pliocene deposits at Split Mountain Gorge, southern California: A record of regional tectonics and Colorado River evolution. Geology, v. 35, p. 57-60. https://doi.org/10.1130/G23139A.1.

Dorsey, R.J., Housen, B.A., Janecke, S.U., Fanning, C.M., and Spears, A.L.F., 2011. Stratigraphic record of basin development within the San Andreas fault system: Late Cenozoic Fish Creek-Vallecito basin, southern California. Geological Society America Bulletin, v. 123, p. 771-793. https://doi.org/10.1130/B30168.1.

Dorsey, R.J., and Lazear, G., 2013. A Post 6-Ma Sediment Budget for the Colorado River. Geosphere, v. 9, p. 781-791. https://doi.org/10.1130/GES00784.1.

Dorsey, R.J., O'Connell, B., McDougall, K., and Homan, M. B., 2018. Punctuated sediment discharge during early Pliocene birth of the Colorado River: Evidence from regional stratigraphy, sedimentology, and paleontology. Sedimentary Geology, vol. 363, p. 1-33, doi:10.1016/j.sedgeo.2017.09.018. https://doi.org/10.1016/j.sedgeo.2017.09.018.

Dorsey, R.J., O'Connell, B., Gardner, K., Homan, M. B., Bennett, S.E.K., Thacker, J.O., and Darin, M.H., 2021 a. Tectonostratigraphic record of late Miocene - early Pliocene transtensional faulting in the eastern California shear zone, southwestern USA. Geosphere, https://doi.org/10.1130/GES02337.1.

Dorsey, R.J., Axen, G.J., Grove, M.J., Housen, B.A., Jefferson, G., McDougall, K., Murray, L., Oskin, M.E., Peryam, T., van Wijk, J.W., and Young, E.K., 2021b. Redefining the age of the lower Colorado River, southwestern United States: COMMENT. Geology, 49 (9): e531. https://doi.org/10.1130/G49145C.1.

Dumas, S., Arnott, R.W.C. and Southard, J.B., 2005. Experiments on oscillatory-flow and combined-flow bed forms: implications for interpreting parts of the shallow-marine sedimentary record. Journal of Sedimentary Research, 75(3), pp. 501-513. https://doi.org/10.2110/isr.2005.039.

Evans, J.E., Maurer, J.T. and Holm-Denoma, C.S., 2019. Recognition and significance of Upper Devonian fluvial, estuarine, and mixed siliciclastic-carbonate nearshore marine facies in the San Juan Mountains (southwestern Colorado, USA): Multiple incised valleys backfilled by lowstand and transgressive systems tracts. Geosphere, 15(5), pp.1479-1507. https://doi.org/10.1130/GES02085.1.

Flügel, E., 2010. Microfacies of carbonate rocks. Analysis, Interpretation and Application. Springer, Berlin Heidelberg. Fridrich, C.J., and Thompson, R.A., 2011. Cenozoic tectonic reorganizations of the Death Valley region, southeast California and southwest Nevada: U.S. Geological Survey Professional Paper 1783, 36 p. and 1 plate. https://pubs.usgs.gov/pp/1783/.

Fujino, S., F. Masuda, S. Tagomori, and D. Matsumoto, 2006. Structure and depositional processes of a gravelly tsunami deposit in a shallow marine setting: Lower Cretaceous Miyako Group, Japan. Sedimentary Geology 187, no. 3-4: 127-138. https://doi.org/10.1016/j.sedgeo.2005.12.021.

Fujiwara, O., 2021. Bedforms and sedimentary structures characterizing tsunami deposits. in Shiki, T., Tsuji, Y., Yamazaki, T., and Nanayama, F. (Eds.) Tsunamiites (Second Edition): Features and Implications, Elsevier, Amsterdam, pp. 53-64. https://doi.org/10.1016/B978-0-12-823939-1.00004-5.

Fujiwara, O., and Kamataki, T., 2008. Tsunami depositional processes reflecting the waveform in a small bay interpretation from the grain-size distribution and sedimentary structures. In: Shiki, T., Tsuji, Y., Yamazaki, T., Minoura, K. (Eds.), Tsunamiites: Features and Implications. Elsevier, Amsterdam, pp. 133-152. https://doi.org/10.1016/B978-0-444-51552-0.00009-6. 
Gardner, K. and Dorsey, R.J., 2021. Mixed carbonate-siliciclastic sedimentation at the margin of a late Miocene tidal strait, lower Colorado River Valley, south-western USA.Sedimentology. Advance online publication, https://doi.org/10.1111/sed.12834.

Gootee, B.F., Pearthree, P.A., House, P.K., Youberg, A., O'Connell, B., Bright, J., 2016a. A sequence-stratigraphic interpretation of the upper bioclastic unit capping the Bouse Formation in the Cibola Area, Arizona and California. In: Reynolds, R.E. (Ed.), 2016 Desert Symposium Proceedings. California State University Desert Studies Center, Zzyzx, CA, pp. 154-159.

Gootee, B.F., Pearthree, P.A., House, P.K., Youberg, A., Spencer, J.E., and O'Connell, B., 2016b, Geologic map of the Cibola 7 1 $12^{\prime}$ Quadrangle and the northwestern part of Cibola SE 7 1 $/ 2$ Q Quadrangle, La Paz County, Arizona, and Imperial County, California. Arizona Geological Survey Digital Map DGM-117, scale 1:24,000, with text.

Gootee et al., 2019, The Trigo sediments: An early Pliocene offlap-sequence recording the demise of paleolake Blythe, lower Colorado River corridor, southwest USA. Geological Society of America Abstracts with Programs, Phoenix, AZ. Vol. 51, No. 5, Abstract \# 134-12.

Granier, B., Dias-Brito, D. and Bucur, I.I., 2008. Calcareous algae from Upper Albian-Cenomanian strata of the Potiguar basin (NE Brazil). Geologia Croatica, 61(2-3), pp.311-320. https://hrcak.srce.hr/30670.

Granier B. \& Dias-Brito D., 2016. On the fossil alga Elianella elegans PFENDER \& BASSE, 1948, and its so-called lookalikes, with description of Elianella brasiliana n.sp. Revision of the Juliette PFENDER Collection. Part 1.Carnets Geol., 16, 213-229. http://hdl.handle.net/11449/161426.

Heidarzadeh, M., Šepić, J., Rabinovich, A., Allahyar, M., Soltanpour, A. and Tavakoli, F., 2020. Meteorological tsunami of 19 March 2017 in the Persian Gulf: observations and analyses. Pure and Applied Geophysics, 177(3), pp.12311259. https://doi.org/10.1007/s00024-019-02263-8.

Helm, C. Schülke, I, Schlagintweit, F., 2003. Calcareous algae ("Porostromata", Rhodophyta, Dasycladales) and microproblematica with algal affinity from the NW German Korallenoolith Formation (Oxfordian, Süntel Mountains). Facies, 49(1), 61-86. https://doi.org/10.1007/s10347-003-0025-y.

Hirschaut, D.W. and Dingler, J.R., 1982. A field study of large-scale oscillation ripples in a very coarse-grained, highenergy marine environment. US Geological Survey Open File Report 82-733, 33 p. https://doi.org/10.3133/ofr82733.

House, P.K., Pearthree, P.A., and Perkins, M.E., 2008, Stratigraphic evidence for the role of lake spillover in the inception of the lower Colorado River in southern Nevada and western Arizona, in Reheis, M.C., Hershler, R., and Miller, D.M. (eds.), Late Cenozoic Drainage History of the Southwestern Great Basin and Lower Colorado River Region: Geologic and Biotic Perspectives. Geological Society of America Special Paper 439, p. 335-353.

Howard, K.A., House, P.K., Dorsey, R.J., and Pearthree, P.A., 2015, River-evolution and tectonic implications of a major Pliocene aggradation on the lower Colorado River, the Bullhead Alluvium: Geosphere, v. 11, p. 1-30; https://doi:10.1130/GES01059.1.

Ingram, B.L., Ingle, J.C., and Conrad, M.E., 1996. A 2000 yr record of Sacramento-San Joaquin river inflow to San Francisco Bay estuary, California. Geology 24, 331-334. https://doi.org/10.1130/00917613(1996)024<0331:AYROSS>2.3.CO;2.

Jansà, A. and Ramis, C., 2021. The Balearic rissaga: from pioneering research to present-day knowledge. Natural Hazards, 106(2), pp. 1269-1297. https://doi.org/10.1007/s11069-020-04221-3.

Johnson, J.H., 1964. Paleocene calcareous red algae from northern Iraq. Micropaleontology, 10, $207-216$.

Johnson, J.H. and Konishi, K.J., 1960. An interesting Late Cretaceous calcareous algae from Guatemala. Journal of Paleontology, 34, 1099-1105. https://www.jstor.org/stable/1300854.

Klein, G.D. (1977) Clastic Tidal Facies. Continuing Education Publication Company, Champaign, IL, 149 pp.

Kleinspehn, K.L., Steel, R.J., Johanssen, E. and Netland, A., 1984, Conglomeratic fan-delta sequences, late Carboniferous-early Permian, Western Spitsbergen. In: Sedimentology of Gravels and Conglomerates (Ed. By E.H. Koster and R.J. Steel). Mem. Can. Soc. Petrol. Geol. 10, pp. 279-294.

Kowalewski, M., Serrano, G.E.A., Flessa, K.W. and Goodfriend, G.A., 2000. Dead delta's former productivity: two trillion shells at the mouth of the Colorado River. Geology, 28(12), pp.1059-1062. https://doi.org/10.1130/00917613(2000)28<1059:DDFPTT>2.0.CO;2.

Kupriyanova, E.K., ten Hove, H.A., Sket, B., Zaksek, V., Trontelj, P., Rouse, G.W., 2009, Evolution of the unique freshwater cave-dwelling tube worm Marifugia cavatica (Annelida: Serpulidae), Systematics and Biodiversity, 7 , 389-401. https://doi:10.1017/S1477200009990168. 
Leckie, D., 1988. Wave-formed, coarse-grained ripples and their relationship to hummocky cross-stratification. Journal of Sedimentary Research 58, 607-622. https://doi.org/10.1306/212F8E04-2B24-11D78648000102C1865D.

Leckie, D.A., and Walker, R.G., 1982. Storm-and tide-dominated shorelines in Cretaceous Moosebar-Lower Gates interval--outcrop equivalents of Deep Basin gas trap in western Canada. American Association Petroleum Geologists Bulletin 66, 138-157.https://doi.org/10.1306/03B59A53-16D1-11D7-8645000102C1865D.

Leeder, M.R. and Gawthorpe, R.L., 1987. Sedimentary models for extensional tilt-block/half-graben basins. Geological Society, London, Special Publications, 28(1), pp.139-152. https://doi.org/10.1144/GSL.SP.1987.028.01.11.

Leinfelder, R. R., 1986. Facies, Stratigraphy and Paleogeogaphic Analysis of Upper? Kimmeridgian to Upper Portlandian Sediments in the Environs of Arrund dos Vinhos, Estremadura, Portugal. - Münchener Geowiss. Abh., A 7, 1-216.

Leithold, E.L., and Bourgeois, J., 1984. Characteristics of coarse- grained sequences deposited in nearshore, wavedominated environments-examples from the Miocene of south-west Oregon. Sedimentology 31, 749-775. https://doi.org/10.1111/j.1365-3091.1984.tb00884.x.

Longhitano, S.G., 2013. A facies-based depositional model for ancient and modern, tectonically-confined tidal straits. Terra Nov., 25, 446-452. https://doi.org/10.1111/ter.12055.

Longhitano, S.G., Chiarella, D. and Muto, F., 2014. Three-dimensional to two-dimensional cross-strata transition in the lower Pleistocene Catanzaro tidal strait transgressive succession (southern Italy). Sedimentology, 61(7), pp.2136-2171. https://doi.org/10.1111/sed.12138.

Longhitano, S.G. and Steel, R.J., 2017, Deflection of the progradational axis and asymmetry in tidal seaway and strait deltas: insights from two outcrop case studies. Geol. Soc. London, Spec. Publ., 444, 141-172. https://doi.org/10.1144/SP444.8.

Longhitano, S.G., Rossi, V.M., Chiarella, D., Mellere, D., Tropeano, M., Dalrymple, R.W., Steel, R.J., Nappi, A. and Olita, F., 2021. Anatomy of a mixed bioclastic-siliciclastic regressive tidal sand ridge: Facies-based case study from the lower Pleistocene Siderno Strait, southern Italy. Sedimentology. https://doi.org/10.1111/sed.12853.

Matmon, A., Stock, G.M., Granger, D.E., and Howard, K.A., 2012. Dating of Pliocene Colorado River sediments; implications for cosmogenic burial dating and the evolution of the lower Colorado River. Geological Society America Bulletin 124, 626-640. https://doi.org/10.1130/B30453.1.

Massari, F. and D'alessandro, A., 2000. Tsunami-related scour-and-drape undulations in Middle Pliocene restrictedbay carbonate deposits (Salento, south Italy). Sedimentary Geology, 135(1-4), pp.265-281.

McDougall, K., 2008, Late Neogene marine incursions and the ancestral Gulf of California, In: Reheis, M.C., Hershler, R., and Miller, D.M. (eds.) Late Cenozoic drainage history of the southwestern Great Basin and lower Colorado River region: Geologic and biotic perspectives. Geological Society of America Special Paper 439, p. 355-373.

McDougall, K., and Miranda Martinez, A.Y., 2014, Evidence for a marine incursion along the lower Colorado River corridor: Geosphere, 10, 1-28. https://doi.org/10.1130/GES00975.1.

Meng, X., Ge, M., Tucker, M. E., 1997. Sequence stratigraphy, sea-level changes and depositional systems in the Cambro-Ordovician of the North China carbonate platform. Sedimentary Geology 114, 189-223. https://doi.org/10.1016/S0037-0738(97)00073-0.

Metzger, D.G., 1968. The Bouse Formation (Pliocene) of the Parker-Blythe-Cibola area, Arizona and California, in Geological Survey Research 1968, Chapter D: U.S. Geological Survey Professional Paper 600-D, p. D126-D136. https://doi.org/10.3133/pp600D.

Metzger, D.G., Loeltz, O.J., and Irelan, B., 1973. Geohydrology of the Parker-Blythe-Cibola area, Arizona and California: U.S. Geological Survey Professional Paper 486-G, 130 p. https://doi.org/10.3133/pp486G.

Michael, N.A., Whittaker, A.C. and Allen, P.A., 2013. The functioning of sediment routing systems using a mass balance approach: example from the Eocene of the southern Pyrenees. The Journal of Geology, 121(6), pp.581606. https://doi.org/10.1086/673176.

Miller, K.G., Mountain, G.S., Wright, J.D., Browning, J.V., 2011. A 180-million-year record of sea level and ice volume variations from continental margin and deep-sea isotopic records. Oceanography 24 (2), 40-53. www.jstor.org/stable/24861267.

Miller, K.G., Browning, J.V., Schmelz, W.J., Kopp, R.E., Mountain, G.S. and Wright, J.D., 2020. Cenozoic sea-level and cryospheric evolution from deep-sea geochemical and continental margin records. Science Advances, 6(20), eaaz1346. https://doi.org/10.1126/sciadv.aaz1346. 
Milliman, J.D. and Meade, R.H., 1983. World-wide delivery of river sediment to the oceans. The Journal of Geology, 91(1), pp.1-21. https://doi.org/10.1086/628741.

Milliman, J.D. and Syvitski, J.P., 1992. Geomorphic/tectonic control of sediment discharge to the ocean: the importance of small mountainous rivers. The journal of Geology, 100(5), 525-544. https://doi.org/10.1086/629606.

Miranda-Martínez, A.Y.M., 2019. Edad de los depósitos marinos asociados a la evolución temprana del Golfo de California (Doctoral dissertation, Instituto de Geología). 248 pp.

Miranda-Martínez, A.Y., Carreño, A.L. and McDougall, K., 2017. The Neogene genus Streptochilus (Brönnimann and Resig, 1971) from the Gulf of California. Marine Micropaleontology, 132, pp.35-52. https://doi.org/10.1016/i.marmicro.2017.05.001.

Monserrat, S., Vilibić, I. and Rabinovich, A.B., 2006. Meteotsunamis: atmospherically induced destructive ocean waves in the tsunami frequency band. Natural hazards and earth system sciences, 6(6), pp.1035-1051. https://doi.org/10.5194/nhess-6-1035-2006.

Morsilli, M. and Pomar, L., 2012. Internal waves vs. surface storm waves: a review on the origin of hummocky crossstratification. Terra Nova, 24(4), pp.273-282. https://doi.org/10.1111/j.1365-3121.2012.01070.x.

Muto, T. and Steel, R.J., 1997. Principles of regression and transgression; the nature of the interplay between accommodation and sediment supply. Journal of Sedimentary Research,67(6), pp.994-1000. https://doi.org/10.1306/D42686A8-2B26-11D7-8648000102C1865D.

Nebelsick, J.H., 1992. The Northern Bay of Safaga (Red Sea, Egypt): an actuopalaeontological approach, III, distribution of echinoids. Beiträge zur Paläontologie von Österreich, 17, 5-79. https://www.zobodat.at/pdf/BeitrPalaeontologie 17 0005-0079.pdf.

Nyborg, T., 2011. Age, Stratigraphy and Depositional Environment of the Pliocene Copper Canyon Formation, Death Valley, California. 285 pp. https://scholarsrepository.llu.edu/etd/48/.

O'Connell, B., 2016. Sedimentology and depositional history of the Miocene-Pliocene southern Bouse Formation, Arizona and California. Unpub. M.S. thesis, University of Oregon, Eugene, Oregon, $148 \mathrm{p}$.

O'Connell, B., Dorsey, R.J., and Humphreys, E.D., 2017. Tidal rhythmites in the southern Bouse Formation as evidence for post-Miocene uplift of the lower Colorado River corridor. Geology 45, 99-102. https://doi.org/10.1130/G38608.1.

O'Connell, B., Dorsey, R.J., Hasiotis, S.T. and Hood, A.V., 2021, Mixed carbonate-siliciclastic tidal sedimentation in the Miocene to Pliocene Bouse Formation, palaeo-Gulf of California. Sedimentology. 68(3) 1028-1068. https://doi.org/10.1111/sed.12817.

O'Connell, L.G., James, N.P., Doubell, M., Middleton, J.F., Luick, J., Currie, D.R., Bone, Y., 2016. Oceanographic controls on shallow-water temperate carbonate sedimentation: Spencer Gulf, South Australia. Sedimentology, 63, 105-135. https://doi.org/10.1111/sed.12226.

Olmsted, F.H., Loeltz, O.J., and Irelan, B., 1973. Geohydrology of the Yuma area, Arizona and California: Water resources of lower Colorado River-Salton Sea area. U.S. Geological Survey Professional Paper 486-H, 227 pp. https://doi.org/10.3133/pp486H.

Paola, C., 2000. Quantitative models of sedimentary basin filling. Sedimentology, v. 47, p. 121-178. https://doi.org/10.1046/i.1365-3091.2000.00006.x.

Paola, C., Mullin, J., Ellis, C., Mohrig, D.C., Swenson, J.B., Parker, G., Hickson, T., Heller, P.L., Pratson, L., Syvitski, J. and Sheets, B., 2001. Experimental stratigraphy. GSA Today, 11(7), pp. 4-9.

Pattiaratchi, C.B. and Wijeratne, E.M.S., 2015. Are meteotsunamis an underrated hazard?. Philosophical Transactions of the Royal Society A: Mathematical, Physical and Engineering Sciences, 373(2053), p.20140377. https://doi.org/10.1098/rsta.2014.0377.

Pearthree, P.A., and House, P.K., 2014, Paleogeomorphology and evolution of the early Colorado River inferred from relationships in Mohave and Cottonwood valleys, Arizona, California, and Nevada: Geosphere, v. 10, p. 11391160. https://doi.org/10.1130/GES00988.1.

Pederson, C.L., McNeill, D.F., Klaus, J.S. and Swart, P.K., 2015. Deposition and diagenesis of marine oncoids: implications for development of carbonate porosity. Journal of Sedimentary Research, 85, 1323-1333. http://dx.doi.org/10.2110/jsr.2015.77.

Pellikka, H., Laurila, T.K., Boman, H., Karjalainen, A., Björkqvist, J.V. and Kahma, K.K., 2020. Meteotsunami occurrence in the Gulf of Finland over the past century. Natural Hazards and Earth System Sciences, 20(9), pp. 2535-2546. 
Peters, G. and van Balen, R.T., 2007. Tectonic geomorphology of the northern Upper Rhine graben, Germany. Global and planetary change, 58(1-4), pp.310-334. https://doi.org/10.1016/j.gloplacha.2006.11.041.

Postma, G., 1990. Depositional architecture and facies of river and fan deltas: a synthesis. In Coarse-grained deltas, Special Publication Int. Association Sedimentologists, 10: 13-27. Blackwell Oxford.

Poulson, S.R. and John, B.E., 2003. Stable isotope and trace element geochemistry of the basal Bouse Formation carbonate, southwestern United States: Implications for the Pliocene uplift history of the Colorado Plateau: Geological Society America Bulletin 115, 434-444. https://doi.org/10.1130/00167606(2003)115<0434:SIATEG>2.0.CO;2.

Rabinovich, A.B., 2020. Twenty-seven years of progress in the science of meteorological tsunamis following the 1992 Daytona Beach event. Pure and Applied Geophysics, 177(3), pp.1193-1230. https://doi.org/10.1007/s00024-019$\underline{02349-3 .}$.

Reid, C.M., James, N.P., Kyser, T.K., Barrett, N. and Hirst, A.J., 2008. Modern estuarine siliceous spiculites, Tasmania, Australia: a non-polar link to Phanerozoic spiculitic cherts. Geology, 36, 107-110. https://doi.org/10.1130/G24333A.1.

Reineck, H.E. and Singh, I.B., 1980. Tidal flats. In Depositional sedimentary environments (pp. 430-456). Springer, Berlin, Heidelberg.

Repasch, M., Karlstrom, K., Heizler, M. and Pecha, M., 2017. Birth and evolution of the Rio Grande fluvial system in the past $8 \mathrm{Ma}$ : Progressive downward integration and the influence of tectonics, volcanism, and climate. EarthScience Reviews, 168, p. 113-164. https://doi.org/10.1016/j.earscirev.2017.03.003.

Richard, S.M., 1993, Palinspastic reconstruction of southeastern California and southwestern Arizona for the middle Miocene: Tectonics, v. 12, p. 830-854. https://doi.org/10.1029/92TC02951.

Riding, R., 2004. Solenopora is a chaetetid sponge, not an alga. Palaeontology, 47(1), 117-122. https://doi.org/10.1111/j.0031-0239.2004.00351.x.

Rodriguez, C.A., Flessa, K.W. and Dettman, D.L., 2001. Effects of upstream diversion of Colorado River water on the estuarine bivalve mollusc Mulinia coloradoensis. Conservation Biology, 15(1), pp.249-258. https://doi.org/10.1111/j.1523-1739.2001.99463.x.

Romans, B.W., Castelltort, S., Covault, J.A., Fildani, A. and Walsh, J.P., 2016. Environmental signal propagation in sedimentary systems across timescales. Earth-Science Reviews 153, 7-1549 29. https://doi.org/10.1016/i.earscirev.2015.07.012.

Roskowski, J.A., Patchett, P.J., Spencer, J.E., Pearthree, P.A., Dettman, D.L., Faulds, J.E. and Reynolds, A.C., 2010, A late Miocene-early Pliocene chain of lakes fed by the Colorado River: Evidence from Sr, C, and O isotopes of the Bouse Formation and related units between Grand Canyon and the Gulf of California: GSA Bulletin, v. 122, p. 1625-1636. https://doi.org/10.1130/B30186.1.

Rossi, V.M., Longhitano, S.G., Mellere, D., Dalrymple, R.W., Steel, R.J., Chiarella, D. and Olariu, C., 2017. Interplay of tidal and fluvial processes in an early Pleistocene, delta-fed, strait margin (Calabria, Southern Italy). Marine and Petroleum Geology, 87, pp.14-30. https://doi.org/10.1016/j.marpetgeo.2017.02.021.

Rossi, V.M., Barbieri, G., Vaiani, S.C., Cacciari, M., Bruno, L., Campo, B., Marchesini, M., Marvelli, S. and Amorosi, A., 2021. Millennial-scale shifts in microtidal ecosystems during the Holocene: dynamics and drivers of change from the Po Plain coastal record (NE Italy). Journal of Quaternary Science. First published 14 May, 2021. https://doi.org/10.1002/jqs.3322.

Russell, M.P., 2013. Echinoderm responses to variation in salinity. Advances in marine biology, 66, pp.171-212. https://doi.org/10.1016/B978-0-12-408096-6.00003-1.

Saltus, R.W., Jachens, R.C., 1995. Gravity and basin-depth maps of the Basin and Range Province, Western United States: U.S. Geological Survey Geophysical Investigations Map 1012, 4 sheets, scale 1:2,500,000. https://doi.org/10.3133/gp1012.

Sarna-Wojcicki, A.M., Deino, A.L., Fleck, R.J., McLaughlin, R.J., Wagner, D., Wan, E., Wahl, D., Hillhouse, J.W., and Perkins, M., 2011. Age, composition, and areal distribution of the Pliocene Lawlor Tuff, and three younger Pliocene tuffs, California and Nevada. Geosphere, v. 7; p. 599-628. https://doi.org/10.1130/GES00609.1.

Sherrod, D.R., and Tosdal, R.M., 1991, Geologic setting and Tertiary structural evolution of southwestern Arizona and southeastern California. Journal of Geophysical Research, v. 96, p. 12,407-12,423. https://doi.org/10.1029/90JB02688. 
Shiki, T., Tachibana, T., Fujiwara, O., Goto, K., Nanayama, F. and Yamazaki, T., 2021. Characteristic features of tsunamiites. in Shiki, T., Tsuji, Y., Yamazaki, T., and Nanayama, F. (Eds.) Tsunamiites (Second Edition): Features and Implications, Elsevier, Amsterdam, pp. 383-404. https://doi.org/10.1016/B978-0-12-823939-1.00020-3.

Simms, A.R., Rodriguez, A.B. and Anderson, J.B., 2018. Bayhead deltas and shorelines: Insights from modern and ancient examples. Sedimentary Geology, 374, pp.17-35. https://doi.org/10.1016/j.sedgeo.2018.07.004.

Sizemore, T., Wielicki, M.M., Çemen, I., Stockli, D., Heizler, M. and Robinson, D., 2019. Structural evolution of central Death Valley, California, using new thermochronometry of the Badwater turtleback. Lithosphere, 11(4), pp.436447. https://doi.org/10.1130/L1044.1.

Skotnicki, S.J., Seong, Y.B., Dorn, R.I., Larson, P.H., DePonty, J. and Jeong, A., 2021. Drainage integration of the Salt and Verde rivers in a Basin and Range extensional landscape, central Arizona, USA. Geomorphology, 374, p.107512. https://doi.org/10.1016/j.geomorph.2020.107512.

Smith, P.B., 1970. New evidence for Pliocene marine embayment along the lower Colorado River area, California and Arizona: Geological Society America Bulletin 81, 1411-1420. https://doi.org/10.1130/00167606(1970)81[1411:NEFAPM]2.0.CO;2.

Smith, A., and Mason, T.R., 2006. Pleistocene, multiple-growth, lacustrine oncoids from the Poacher's Point Formation, Etosha Pan, northern Namibia, Sedimentology, 38, 591-599. https://doi.org/10.1111/i.13653091.1991.tb01010.x

Sohn, Y.K. and Son, M., 2004. Synrift stratigraphic geometry in a transfer zone coarse-grained delta complex, Miocene Pohang Basin, SE Korea. Sedimentology,51(6), pp. 1387-1408. https://doi.org/10.1111/j.13653091.2004.00679.x.

Spencer, J.E., and Patchett, P.J., 1997, Sr isotope evidence for a lacustrine origin for the upper Miocene to Pliocene Bouse Formation, lower Colorado River trough, and implications for timing of Colorado Plateau uplift. Geological Society of America Bulletin, v. 109, p. 767-778. https://doi.org/10.1130/00167606(1997)109<0767:SIEFAL>2.3.CO;2.

Spencer, J.E., Pearthree, P.A., and House, P.K., 2008, An evaluation of the evolution of the latest Miocene to earliest Pliocene Bouse lake system in the lower Colorado River valley, southwestern USA, in Reheis, M.C., Hershler, R., and Miller, D.M., eds., Late Cenozoic drainage history of the southwestern Great Basin and lower Colorado River region: Geologic and biotic perspectives. Geological Society of America Special Paper 439, p. 375-390.

Spencer, J.E., Patchett, P.J., Pearthree, P.A., and House, P.K., Sarna-Wojcicki, A.M., Wan, E., Roskowski, J.A., and Faulds, J.E., 2013, Review and analysis of the age and origin of the Pliocene Bouse Formation, lower Colorado River Valley, southwestern USA. Geosphere, v. 9, p. 444-459. https://doi.org/10.1130/GES00896.1.

Taylor, D.W. (1983) Late Tertiary mollusks from the Lower Colorado River valley. University of Michigan Contributions from the Museum of Paleontology, 26, 289-298.

Telesca, D., Longhitano, S.G., Pistis, M., Pascucci, V., Tropeano, M. and Sabato, L., 2020. Sedimentology of a transgressive middle-upper Miocene succession filling a tectonically confined, current dominated seaway (the Logudoro Basin, northern Sardinia, Italy). Sedimentary Geology, 400, p.105626. https://doi.org/10.1016/i.sedgeo.2020.105626.

Vilibić, I., Rabinovich, A.B. and Anderson, E.J., 2021. Special issue on the global perspective on meteotsunami science. Pp. 1-18. https://doi.org/10.1007/s11069-021-04679-9.

Zecchin, M., Catuneanu, O. and Caffau, M., 2019. Wave-ravinement surfaces: Classification and key characteristics. Earth-science reviews, 188, pp.210-239. https://doi.org/10.1016/j.earscirev.2018.11.011.

Zeneli, V. and Kashta, L., 2016. Some Charophyta (Charales) from coastal temporary ponds in Velipoja area (North Albania). Journal of Environmental Science and Engineering B,5, pp.69-77. D0I:10.17265/2162$\underline{5263 / 2016.02 .002}$. 


\section{Figure Captions}

Figure 1. A. Map of major rivers in the western U.S., with Colorado River (C.R.) catchment highlighted in yellow. B. Map of the lower Colorado River region showing faults of the San Andreas fault system and eastern California shear zone (ECSZ), northern and southern surface exposures of the Bouse Formation (purple), modern dry lakes (yellow), and inferred distribution of Bouse sedimentary basins (light blue). A, Amboy; B, Blythe; BWRFZ, Bill Williams River fault zone; DV, Death Valley; FCF, Furnace Creek fault; GF, Garlock fault; GoC, Gulf of California; LV, Las Vegas; N, Needles; NRM, northern Riverside Mountains; P, Parker; PS, Palm Springs; SAF, San Andreas Fault; SLF, Stateline fault; SMG, Split Mt. Gorge; ST, Salton Trough; Y, Yuma.

Figure 2. A. Simplified geologic map of the southern Blythe basin and surrounding ranges (location in Fig. 1), showing line of cross-basin stratigraphic panel (Fig. 4), location of the geologic map of SE Palo Verde Mts. (Fig. 5), and exposures of the Bouse Formation (blue polygons and filled circles). WTM is western Trigo Mts. area (see Dorsey et al., 2021a, for details). B. Paleogeographic reconstruction of fault-controlled tidal strait that existed in the lower Colorado River Valley during deposition of the basal carbonate member of the Bouse Formation (modified from Gardner and Dorsey, 2021). Bold blue outlines show present-day exposures of the Bouse Formation. Dashed heavy lines are inferred syn-depositional faults. Plus and minus signs indicate direction (uplift or subsidence) of inferred vertical crustal motions during deposition and basin formation.

Figure 3. Schematic stratigraphy of the southern Blythe basin with the Bouse Formation highlighted in blue box (modified from Dorsey et al., 2021a; approximate ages from Dorsey et al., 2018). ${ }^{* *}=$ ca. $5.4-$ 6.3(?) Ma. The Bouse upper bioclastic member (Tbu), focus of this study, overlies older members of the Bouse Formation along a regional unconformity. FA1, FA2, and FA3 represent facies associations of Tbu. Tfg2 is alluvial-fan conglomerate that conformably overlies Tbu. C.R. is Colorado River. Bullhead is the Pliocene Bullhead alluvium which overlies and is erosionally inset into the Bouse Formation and Tfg2 (Howard et al., 2015; Gootee et al., 2016a, 2016b).

Figure 4. Reconstructed stratigraphic architecture of the southern Blythe basin, hung from base of the ca. 5-Ma upper bioclastic member (Tbu) of the Bouse Formation. Red lines are regional unconformities. Stratal relationships provide a record of fault-controlled tilting toward the basin center during deposition of the basal carbonate (Tbb) and siliciclastic (Tbs) members of the Bouse Formation, prior to deposition of Tbu and overlying alluvial fan gravels (Tfg2). Tfg1 is lower alluvial-fan conglomerate; Tvx is Tertiary volcanics and older crystalline rocks. Modified from Dorsey et al. (2021a), location shown in Fig 2.

Figure 5. Geologic map of a portion of the southeastern Palo Verde Mountains (modified from Gardner, 2019), showing locations of measured sections and line of stratigraphic panel in Figure 6. Map location is shown in Fig. 2, and lies just west of area covered by geologic map of Gootee et al. (2016).

Figure 6. Stratigraphic panel in the southeast Palo Verde Mountains showing stratal architecture in which the upper bioclastic member overlies gently dipping strata and a growth monocline in older members of the Bouse Formation (location in Fig. 5; modified from Dorsey et al., 2021a). Datums (red lines) are regional unconformity at base of the Bouse upper bioclastic member, and conformable base of Tfg2 upper alluvial-fan conglomerate. Stratal wedging and pinch-out geometry provides evidence for tilting toward the basin center during deposition of the Bouse siliciclastic member (Tbs), with gentle tilting likely also during the upper bioclastic member (Tbu). Subtle basinward thickening in the upper bioclastic member observed here is not visible at the regional scale of the cross-basin panel (Fig. 4).

Figure 7. Field photos of unconformity at base of the upper bioclastic member (location of all photos in Table S1). A. View looking southeast at unconformity in the western Trigo Mountains, where a zone of karst fissures and weathering overprints and partially obscures primary bedding in subtidal marl of the Bouse basal carbonate member directly beneath the contact. All members of the Bouse Formation are 
cut by the Lost Trigo fault near the east (left) side of photo (Dorsey et al., 2021a). B. Exposure of unconformity in Milpitas Wash where stratified grainstone and pebbly grainstone of the upper bioclastic member are erosionally inset into subtidal marl of the Bouse basal carbonate member with $\sim 0.5-1.0 \mathrm{~m}$ of local erosional relief. At the regional scale (Fig. 4) the contact is a planar feature that does not show small-scale erosional channels as shown here. Hammer (in red circle) is $32.5 \mathrm{~cm}$ long. C. Example in Palo Verde Mountains where carbonate-clast conglomerate (rudstone) rests unconformably on marl of the Bouse basal carbonate member and lowest claystone bed of the siliciclastic member. D. Vertical exposure of section KG10 (Figs. 5, 6) in the Palo Verde Mountains, where $~ 5.5 \mathrm{~m}$ of red mudstone with minor sandstone of the Bouse siliciclastic member rests on tidal facies of the basal carbonate member, and is unconformably overlain by thin-bedded grainstone of the upper bioclastic member.

Figure 8. Vertical exposure of the upper bioclastic member at site KG12 in the Palo Verde Mountains (Fig. 5), showing interbedded upward coarsening of facies from FA1 to FA3 and conformable contact with overlying upper alluvial-fan conglomerate (Tfg2). Sharp contact with the Bouse siliciclastic member (Tbs) is visible at bottom of photo. Hammer is $32.5 \mathrm{~cm}$ long.

Figure 9. Field photos of facies association 1 (FA1): carbonate-rich bioclastic grainstone and minor red mudstone. A. Horizontally stratified sandy grainstone unconformably overlying Colorado River sandstone of the siliciclastic member (Tbs), overlain by FA2 pebbly grainstone. Locality KG12, southeast Palo Verde Mts (Figs. 5, 6). Hammer is $32.5 \mathrm{~cm}$ long. (B) Horizontally stratified and wave ripple-laminated sandy grainstone with thin beds of red mudstone. C. Well-sorted, thin-bedded ripple cross-laminated sandy grainstone alternating with thin to very thin red mudstone beds (recessive layers). Intervals on measuring stick are $10 \mathrm{~cm}$. D. Flat-based wave-formed ripple bedform in carbonate-rich bioclastic grainstone. Pen is $13.5 \mathrm{~cm}$ long. E. Very thin-bedded well sorted fine-grained grainstone and sandy grainstone; resistant white layers are nearly $100 \%$ carbonate $(b / s$ ratio $>1)$ while darker recessive layers have a $b / s$ ratio $\sim 1$. The high degree of compositional segregation, sorting, and planar bedding records traction transport and deposition by high-energy shallow-marine currents. F. Close-up view of well sorted fine-grained sandy bioclastic grainstone composed of barnacle and molluscan shell fragments, and a small clam shell heavily encrusted with small barnacles and coated with calcareous algae. Hammer is $32.5 \mathrm{~cm}$ long.

Figure 10. Field photos of facies associations FA2 (A, B) and FA3 (C-F). A. Pebbly and sandy grainstone with symmetrical chevron-style gravelly wave-formed ripple cross-bedding. B. Pebbly grainstone with gravelly wave-formed ripple cross-bedding. C. Calcareous-matrix conglomerate with long-wavelength ( $\lambda$ $\sim 1.7-2.3 \mathrm{~m}$ ), low-amplitude hummocky and swaley cross-stratification. Hammer is $32.5 \mathrm{~cm}$ long. $D$. Matrix-rich, poorly sorted calcareous-matrix pebble-cobble conglomerate with subangular to wellrounded clasts of volcanic and granitic rocks. E. Clast-supported calcareous-matrix conglomerate showing well organized imbrication of well-rounded pebble clasts. F. View looking NNE at cross-bedded cobble to small boulder conglomerate with imbricated clasts indicating transport to the ESE, away from the Palo Verde Mountains consistent with dip direction of cross-bed foresets. The conglomerate conformably overlies an interval of sharp-based normally-graded beds of massive pebbly grainstone (FA2) that grade up to planar and trough cross-stratified sandy grainstone (FA1) with isolated clasts and clast pockets that are locally imbricated. F-up is fining-up. Color increments on Jacob's staff are $10 \mathrm{~cm}$.

Figure 11. Detail of gravelly wave-formed ripple cross-bedding in sandy and pebbly grainstone at site KG12 in the Palo Verde Mountains (Figs. 5, 8). Black lines highlight internal cross-bedding and external bounding surfaces that reveal a variety of diagnostic wave-formed ripple cross-bed geometries. Ripple bedform wavelengths in this exposure increase up-section from $\sim 0.25 \mathrm{~m}$ at the bottom to $\sim 2.6 \mathrm{~m}$ at the top, suggesting an increase in water depth during deposition of this interval. Hammer is $32.5 \mathrm{~cm}$ long. See text for discussion. 
Figure 12. Photos of coralline-like calcareous red algae in the upper bioclastic member showing characteristic upward-branching segmented form with variable degrees of rounding and abrasion. A. Rare example of in-situ upright specimen in growth position, buried by poorly sorted matrix of calcareousmatrix conglomerate (FA3). B. Specimen in conglomerate matrix, inferred to be preserved near its growth habitat and toppled over by short-distance transport. C. Typical preservation of the calcareous red algae as a rounded and abraded clast in calcareous-matrix conglomerate. D. Another example of typical preservation, as an abraded clast in coarse sandy pebbly shell hash. E. Specimen S190124-13 collected from section PVM4 in the Palo Verde Mountains. In photos A, C, D, the sharpie pen is $13.5 \mathrm{~cm}$ long (black cap is $5 \mathrm{~cm}$ ). Hand lens in E is $6 \mathrm{~cm}$ long. F, G, specimen BD190122-1 collected in the Palo Verde Mountains. Locations of all photos, sample sites, and fossil specimens provided in Table S1.

Figure 13. Two detailed measured sections through the upper bioclastic member in the Palo Verde Mountains, showing vertical arrangement of facies associations FA1 to FA3 and results of microfossil analysis. A. Section PVM-3. B. Section PVM-4. * indicates occurrence of Chara fragments. Locations shown in Fig. 5; data provided in Table S2.

Figure 14. Other fossils in the upper bioclastic member. A. Typical example of fossil fragments concentrated on a bedding plane in sandy grainstone. B. Clams resembling Mulinia (typical of marine or brackish water) concentrated and aligned in shell bed with barnacles and gastropods. C. Photomicrograph showing an oblique cross-section view of an echinoid spine indicated by the central hole or medulla (M), intermediate radiating layer (RL) recrystallized and converted to micrite in this view, and dense outer cortex (C). D. SEM image of an echinoid spine fragment. E. SEM image of an echinoid spine fragment showing preserved tapered tip of the spine. F, G. Photomicrographs showing cross-section views of micritized serpulid-worm tubes with internal foraminifers and ostracods in sparry calcite. H. Laminated oncoidal carbonate crust (cc) coating the outside of coralline-like algae (Al) showing irregular micritic to microspar laminae.

Figure 15. Oblique-perspective reconstructions of the lower Colorado River region during deposition of the three members of the Bouse Formation (see Dorsey et al., 2018 and 2021a, for details). A. Basal carbonate member formed in a shallow inland sea and fault-bounded tidal strait at the north end of the paleo-Gulf of California, prior to arrival of the Colorado River. B. The siliciclastic member records deposition in the earliest through-flowing Colorado River and delta system. The delta prograded rapidly south to the Salton Trough and delivered sand via turbidity currents to an offshore submarine canyon in the Fish Creek-Vallecito basin (FCVB). C. The upper bioclastic member (this study) formed in a shallow marine bay located seaward of the backstepping Colorado River delta during regional transgression and re-flooding of the former tidal strait. Pink lines show position of transects in parts $D$ and $E$. Map scale is approximate. D. Interpretive stratigraphic panel along the Blythe basin showing main stratal elements of the Bouse Formation including inferred lateral correlation of the upper bioclastic member in the south (Palo Verde Mountains; PVM) to fine-grained deltaic facies of a bayhead delta in the north (Parker). Arrows on right indicate transgression (Tr) and regression (Re). TRS = transgressive ravinement surface. $E$. Interpretive cross-basin panel showing structurally controlled thickening of the siliciclastic member into the basin depocenter and pinch-out at basin margins where the upper bioclastic member unconformably overlies the basal carbonate member (Dorsey et al., 2021a). Transgression and backstepping of the delta likely resulted from fault-controlled sediment trapping along the fluvial routing system in up-system faultbounded basins (i.e., Needles area) and a rise in relative sea level due to tectonic subsidence in the fluvial lowland south of Parker. Map abbreviations in A - C: BWRFZ, Bill Williams River fault zone; Choc. Mtns., Chocolate Mountains; ECSZ, Eastern California Shear Zone; ETR, Eastern Transverse Ranges; FCVB, Fish Creek - Vallecito basin; LFS, Laguna fault system; NRM, northern Riverside Mountains; PVM, Palo Verde Mountains; SAF, San Andreas fault; SLF, State Line fault; TM, Trigo Mountains; WSDF, west Salton detachment fault. 


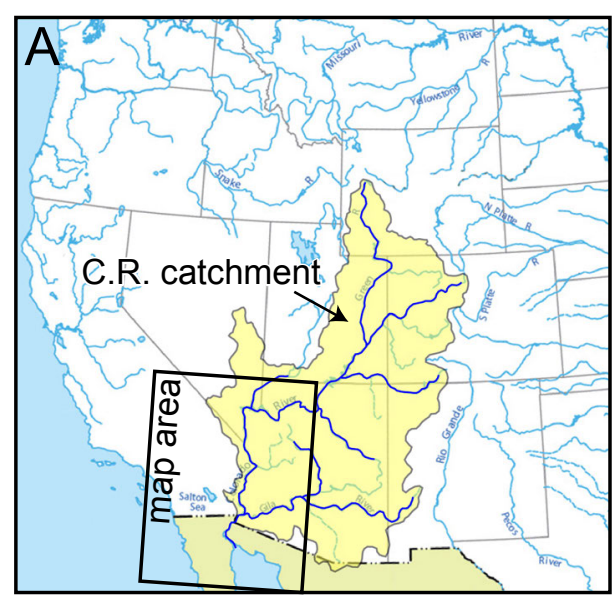

Figure 1. (A) Map of major rivers in the western U.S., with Colorado River (C.R.) catchment highlighted in yellow.

(B) Map of the lower Colorado River region showing faults of the San Andreas fault system and eastern California shear zone (ECSZ), northern and southern surface exposures of the Bouse Formation (purple), modern dry lakes (yellow), and inferred distribution of Bouse sedimentary basins (light blue). A, Amboy; B, Blythe; BWRFZ, Bill Williams River fault zone; DV, Death Valley; FCF, Furnace Creek fault; GF, Garlock fault; GoC, Gulf of California; LV, Las Vegas; $\mathrm{N}$, Needles; NRM, northern Riverside Mountains; P, Parker; PS, Palm Springs; SAF, San Andreas Fault; SLF, Stateline fault; SMG, Split Mt. Gorge; ST, Salton Trough; Y, Yuma.

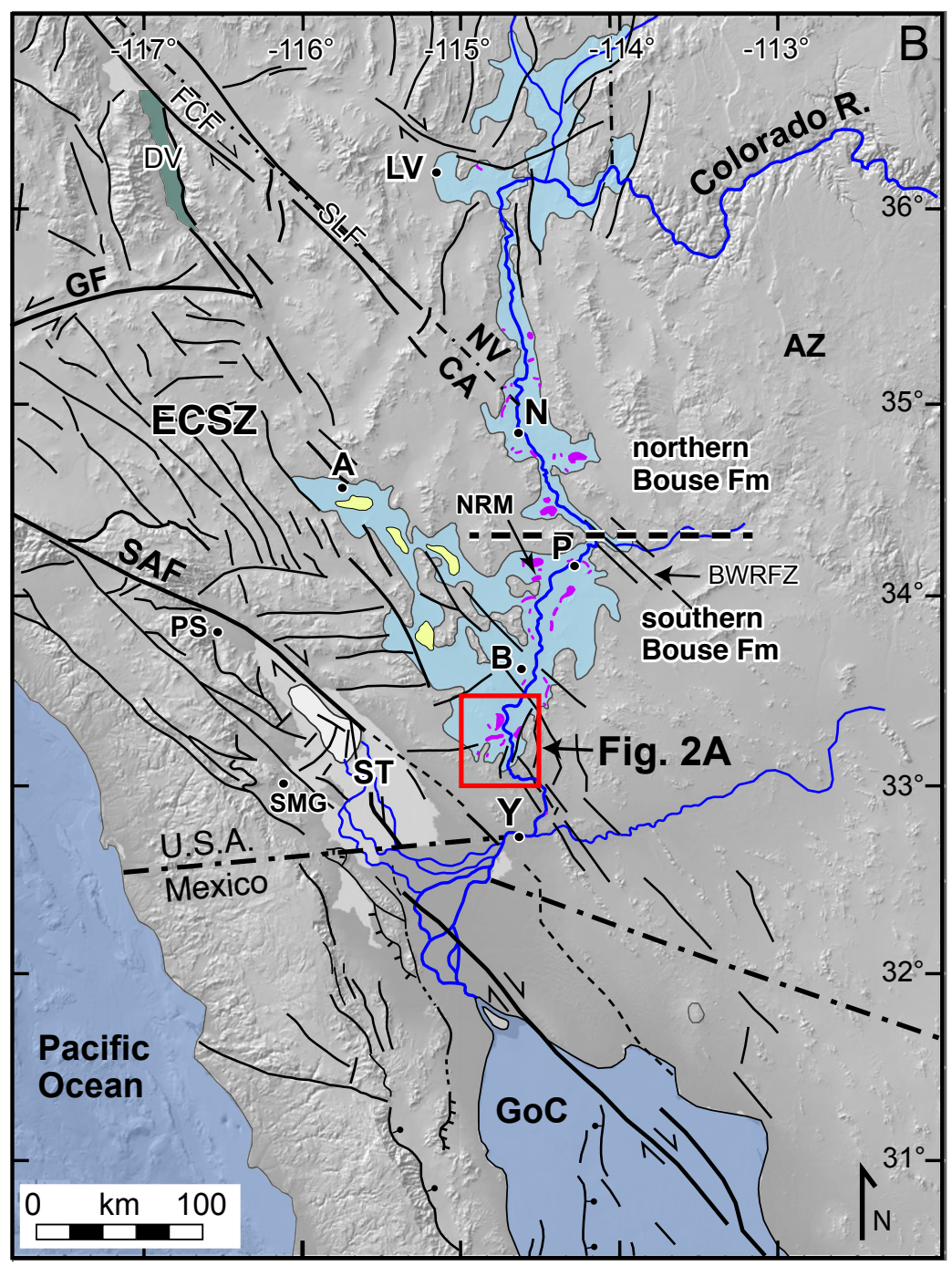




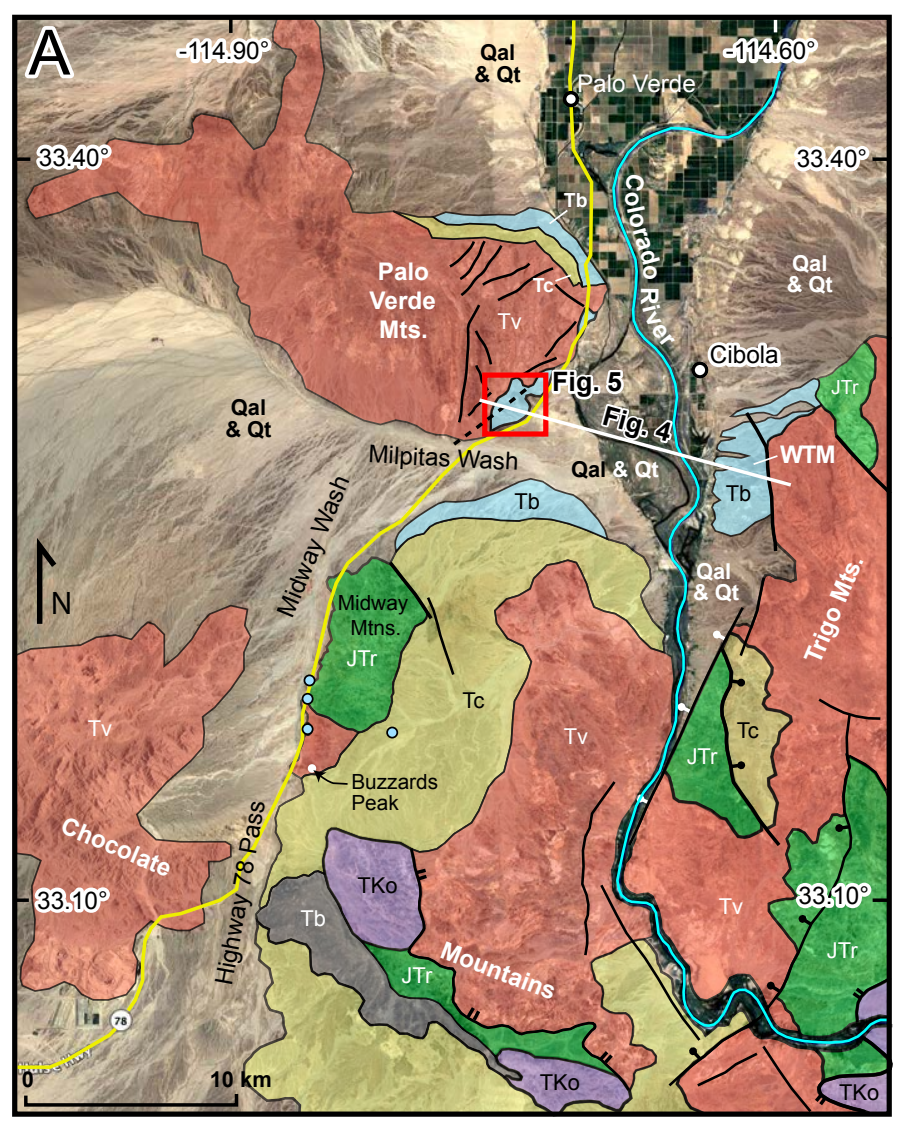

TKo Late Cretaceous to Early Tertiary Orocopia Schist

JTr Triassic-Jurassic metavolcanic and metasedimentary rocks
Tb Tertiary basalt

Oligocene to Miocene volcanic rocks

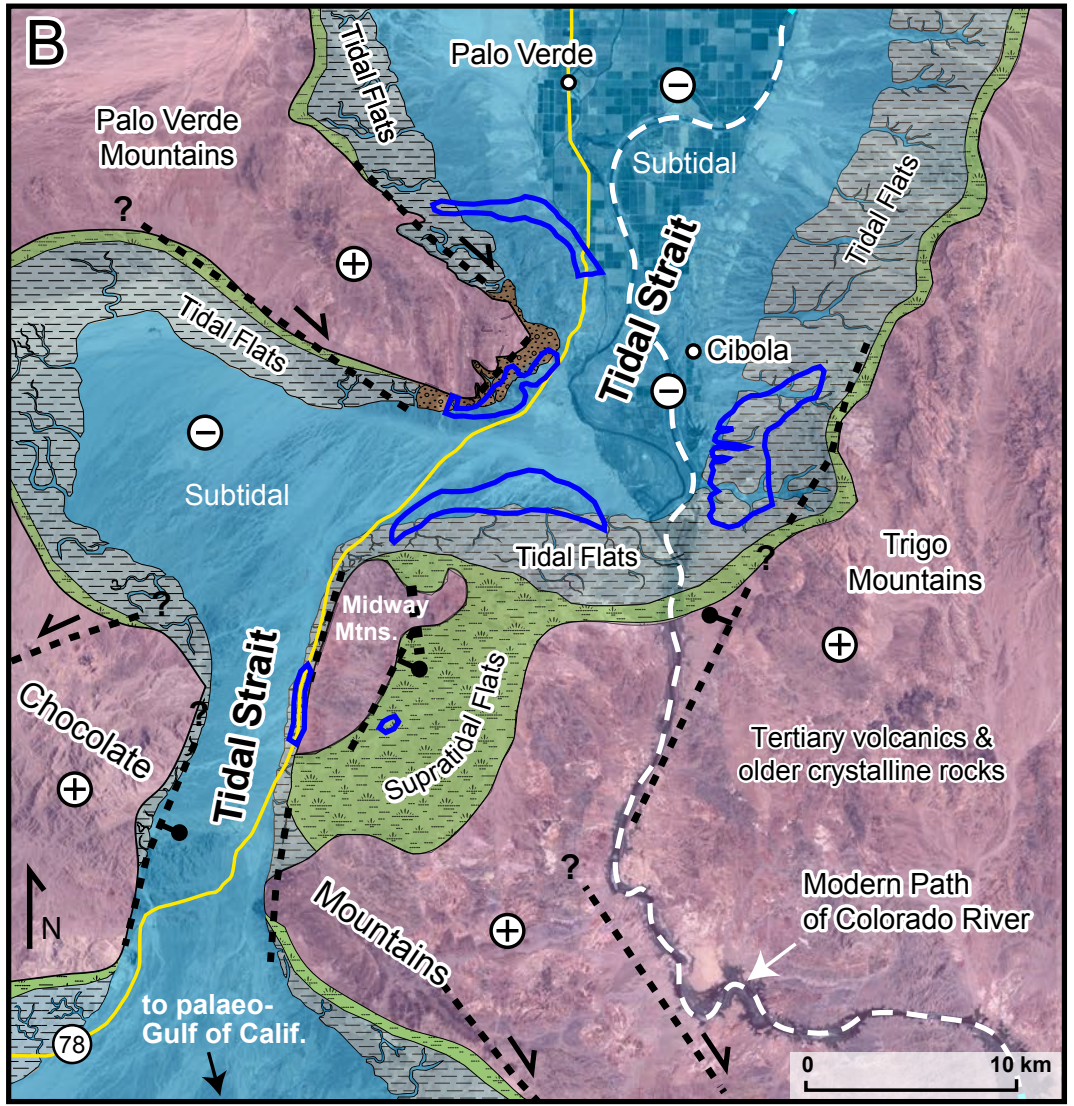

$\mathrm{Tb} \circ$ Bouse Formation (Upper Miocene to lower Pliocene)

Qal + Qt

Quaternary terrace gravels and alluvium

Tc $\begin{aligned} & \text { Miocene } \\ & \text { conglomerate }\end{aligned}$

Figure 2. (A) Simplified geologic map of the southern Blythe basin and surrounding ranges (location in Fig. 1), showing line of cross-basin stratigraphic panel (Fig. 4), geologic map of SE Palo Verde Mts. (Fig. 5), and exposures of the Bouse Formation (blue polygons and filled circles). WTM is western Trigo Mts. area (see Dorsey et al., 2021, for details). (B) Paleogeographic reconstruction of fault-controlled tidal strait that existed in the lower Colorado River Valley during deposition of the basal carbonate member of the Bouse Formation (modified from Gardner and Dorsey, 2021). Bold blue outlines show present-day exposures of the Bouse Formation. Dashed heavy lines are inferred syn-depositional faults. Plus and minus signs indicate direction (uplift or subsidence) of inferred vertical crustal motions during deposition and basin formation. 


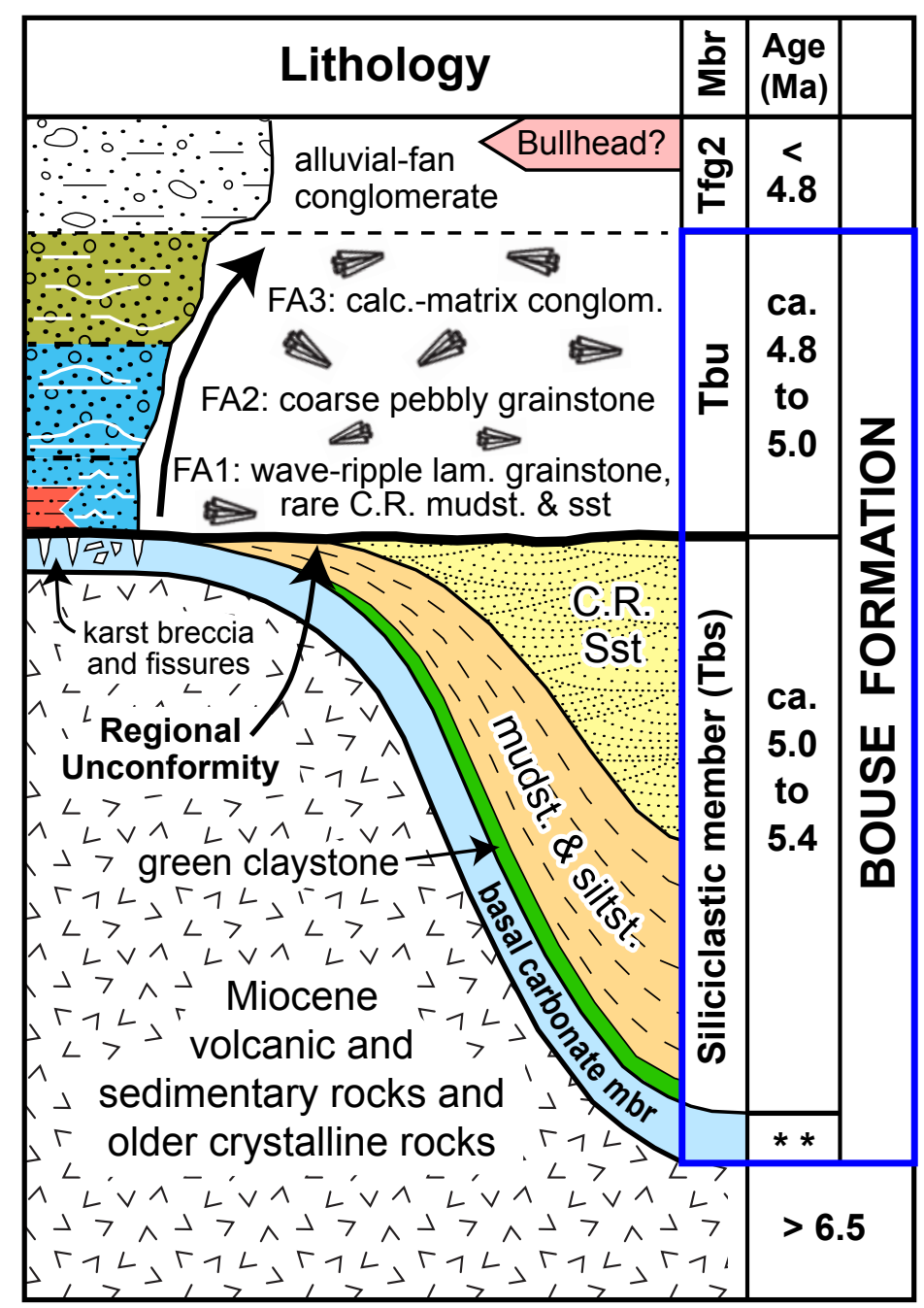

Figure 3. Schematic stratigraphy of the southern Blythe basin with Bouse Formation highlighted in blue box (modified from Dorsey et al., 2021; approximate ages from Dorsey et al., 2018). ${ }^{* *}=$ ca. 5.4 to 6.3(?) Ma. The Bouse upper bioclastic member (Tbu), focus of this study, overlies older members of the Bouse Formation along a regional unconformity. FA1, FA2, and FA3 represent facies associations of Tbu. Tfg2 is alluvial-fan conglomerate that conformably overlies Tbu. C.R. is Colorado River. Bullhead is the Pliocene Bullhead alluvium which overlies and is erosionally inset into Tfg2 and the Bouse Formation (Howard et al., 2015; Gootee et al., 2016b). 


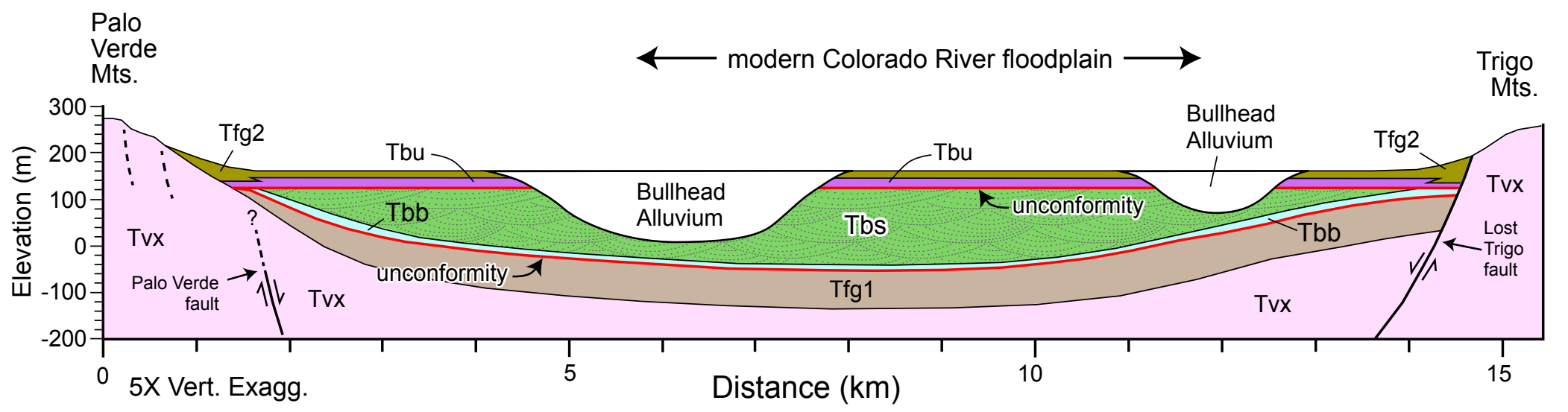

Figure 4. Reconstructed stratigraphic architecture of the southern Blythe basin, hung from base of the ca. 5-Ma upper bioclastic member (Tbu) of the Bouse Formation. Red lines are regional unconformities. Stratal relationships provide a record of fault-controlled tilting toward the basin center during deposition of the basal carbonate (Tbb) and siliciclastic (Tbs) members of the Bouse Formation, prior to deposition of Tbu and overlying alluvial fan gravels (Tfg2). Tfg1 is lower alluvial-fan conglomerate; Tvx is Tertiary volcanics and older crystalline rocks. Modified from Dorsey et al. (2021a), location shown in Fig 2. 


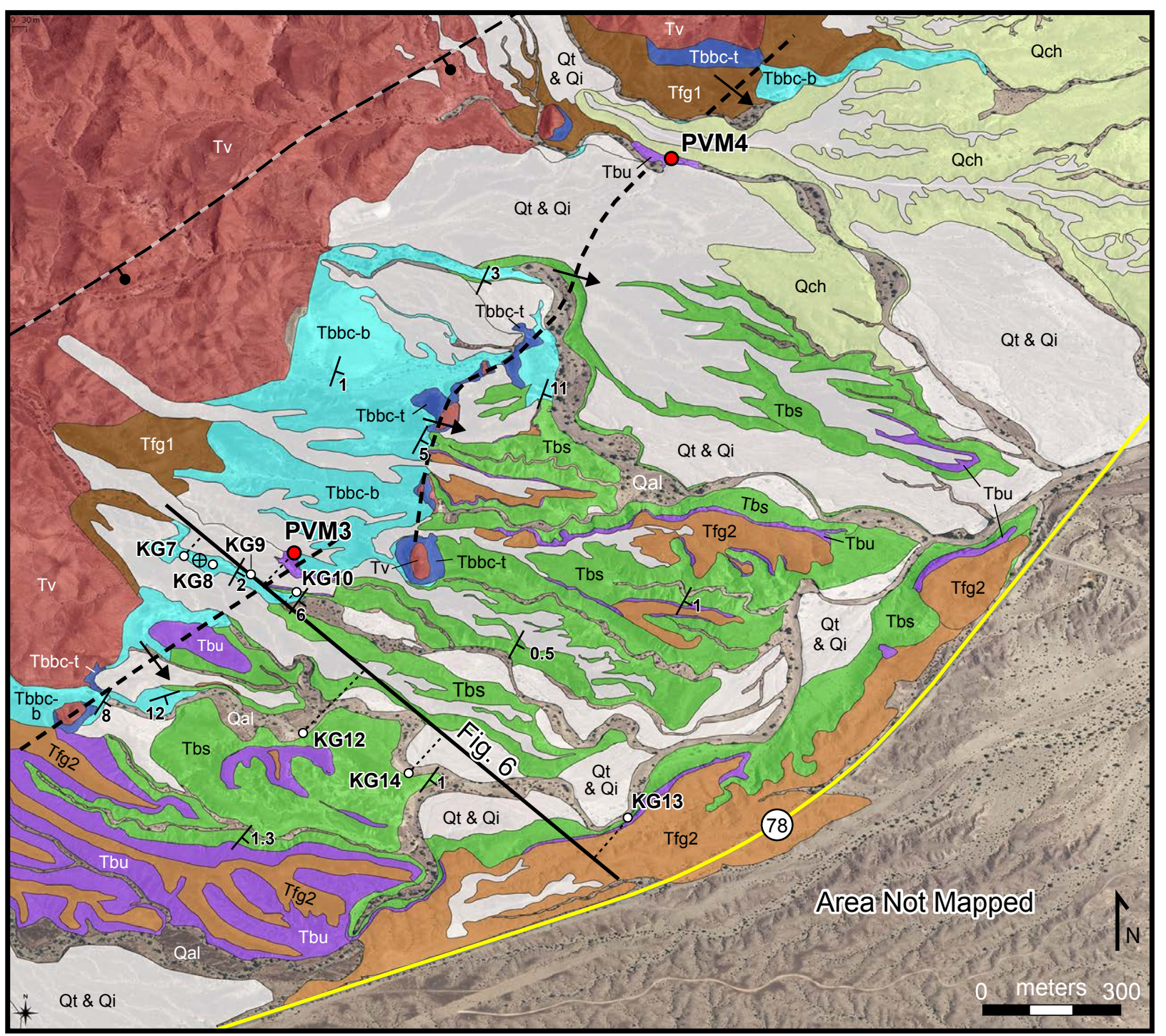

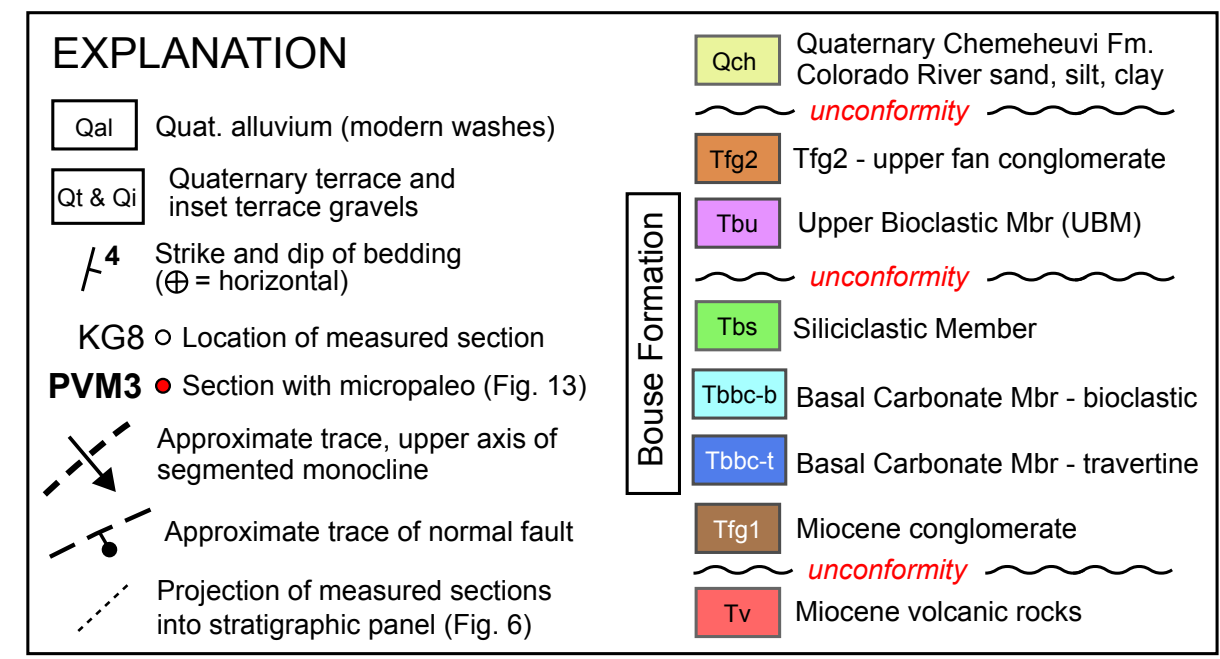

Figure 5. Geologic map of a portion of the southeastern Palo Verde Mountains (modified from Gardner, 2019), showing locations of measured sections and line of stratigraphic panel in Figure 6. Map location is shown in Fig. 2, and lies just west of area covered by the geologic map of Gootee et al. (2016). 


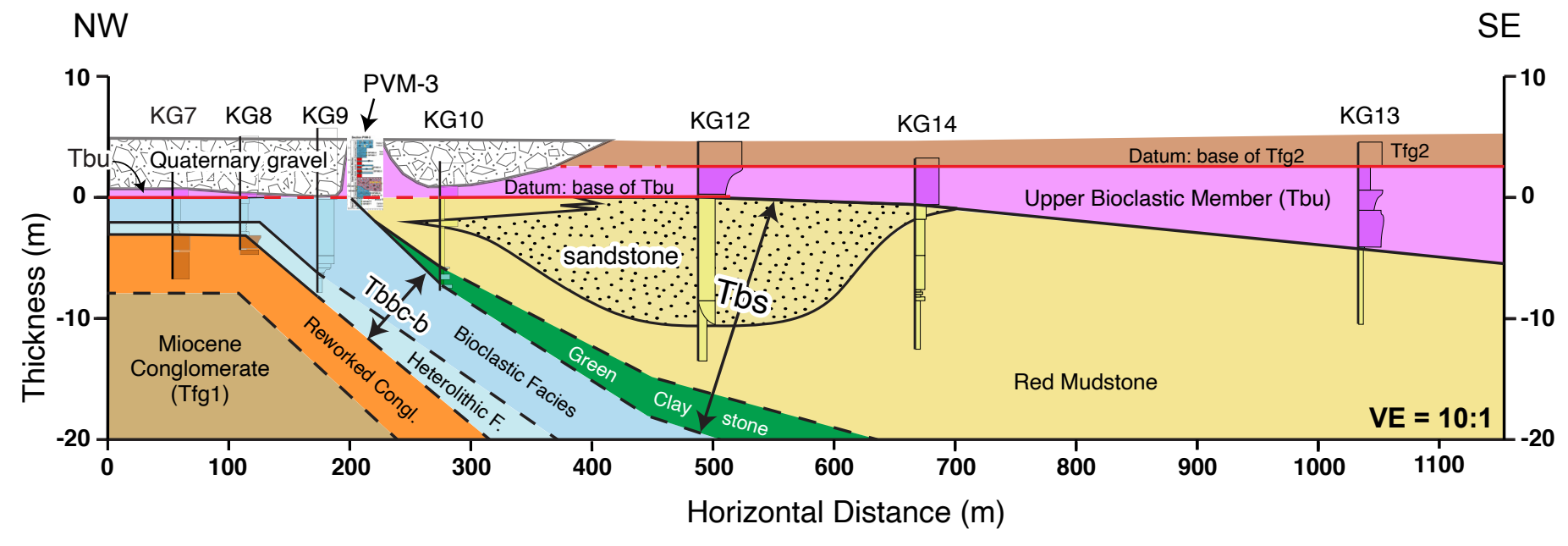

Figure 6. Stratigraphic panel in the southeast Palo Verde Mountains showing stratal architecture in which the upper bioclastic member overlies gently dipping strata and a growth monocline in older members of the Bouse Formation (location in Fig. 5; modified from Dorsey et al., 2021). Datums (red lines) are regional unconformity at base of the Bouse upper bioclastic member, and conformable base of Tfg2 upper alluvial-fan conglomerate. Stratal wedging and pinch-out geometry provides evidence for tilting toward the basin center during deposition of the Bouse siliciclastic member (Tbs), with likely gentle tilting also during the upper bioclastic member (Tbu). Subtle basinward thickening in the upper bioclastic member observed here is not visible at the regional scale of the cross-basin panel (Fig. 4). 


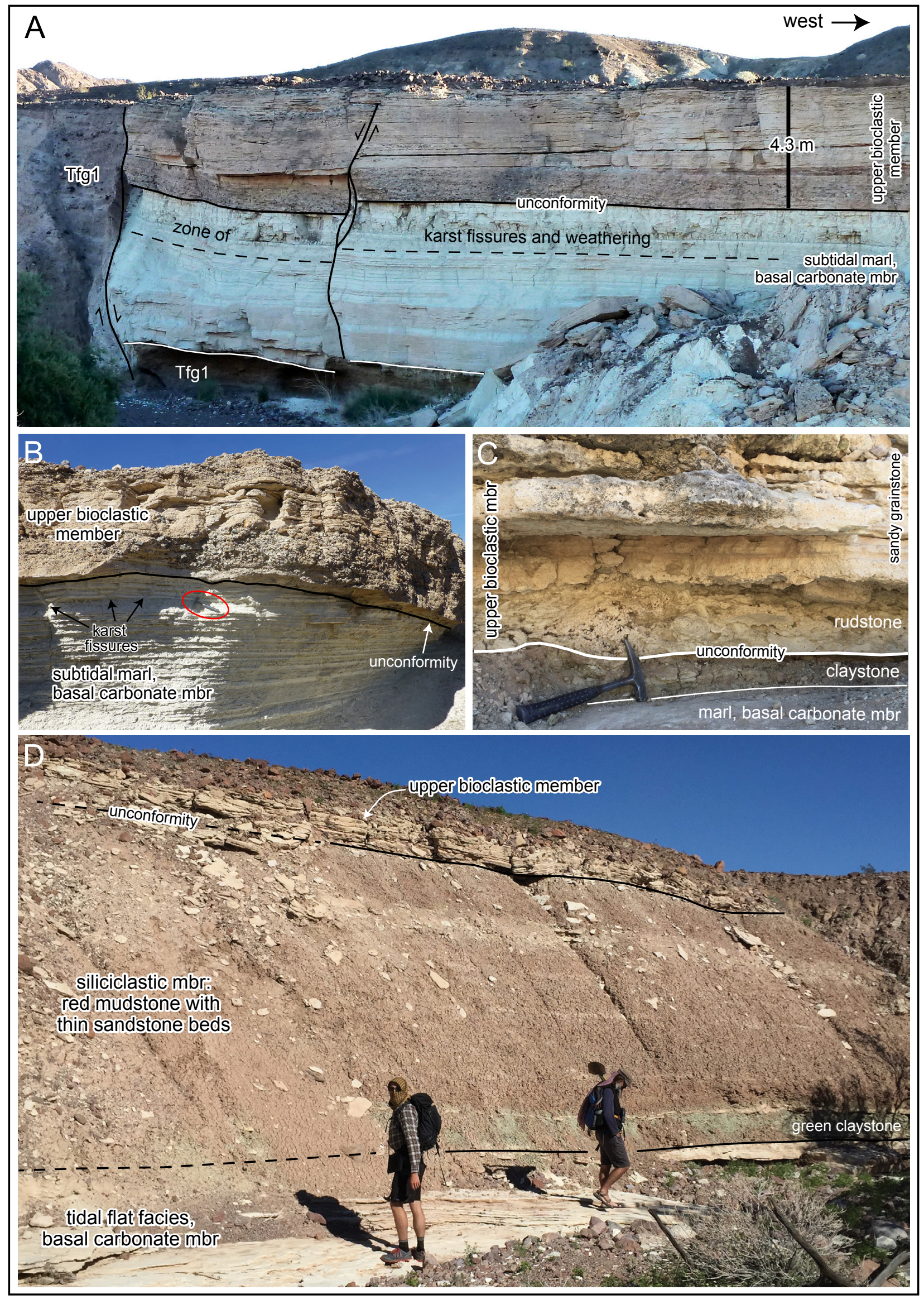

Figure 7. Unconformity at base of the Bouse Formation upper bioclastic member. Caption in text. 


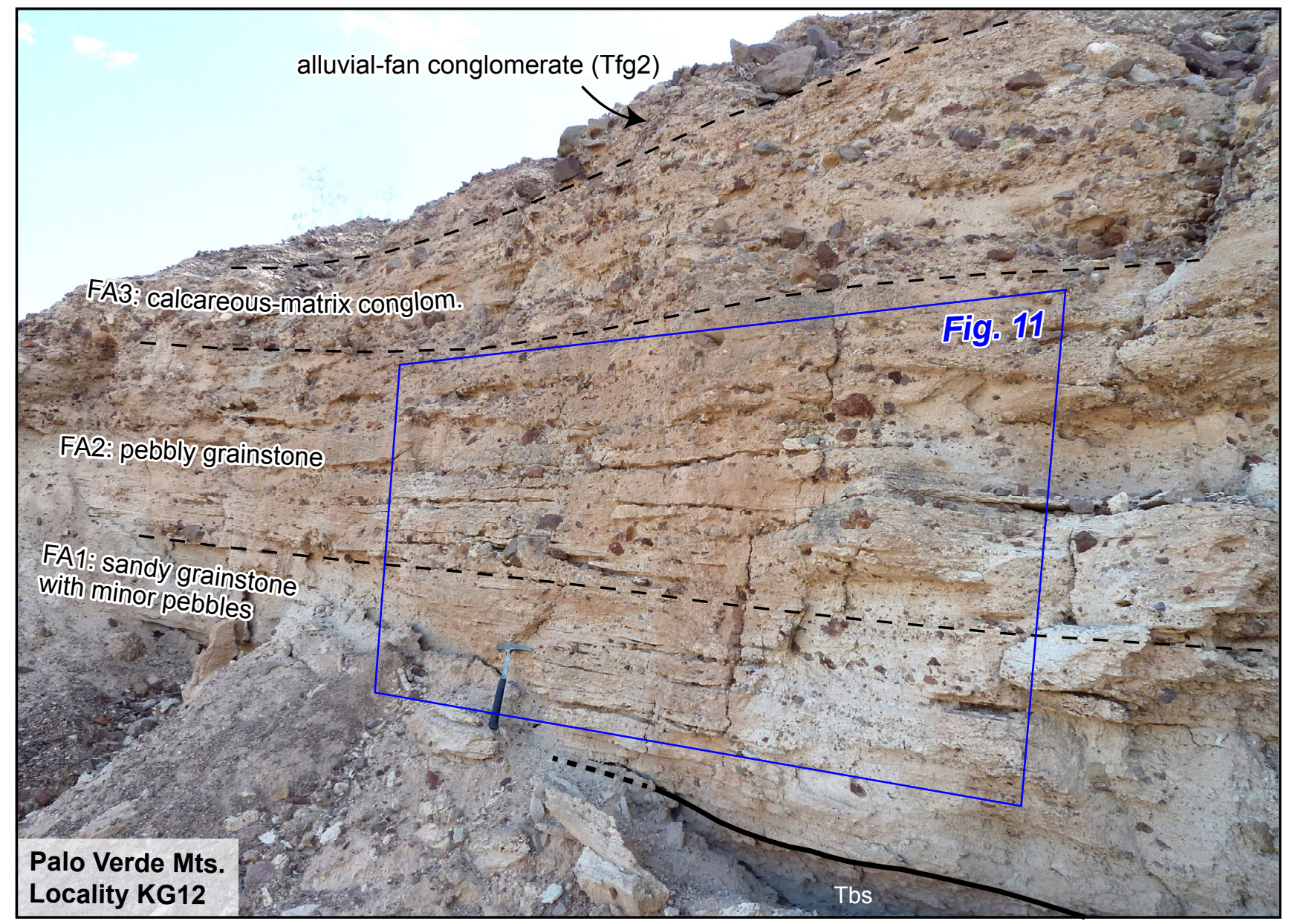

Figure 8. Vertical exposure of the upper bioclastic member at site KG12 in the Palo Verde Mountains (Fig. 5), showing interbedded upward coarsening of facies from FA1 to FA3 and conformable contact with overlying upper alluvial-fan conglomerate (Tfg2). Sharp contact with the Bouse siliciclastic member (Tbs) is visible at bottom of photo. Hammer is $32.5 \mathrm{~cm}$ long. 


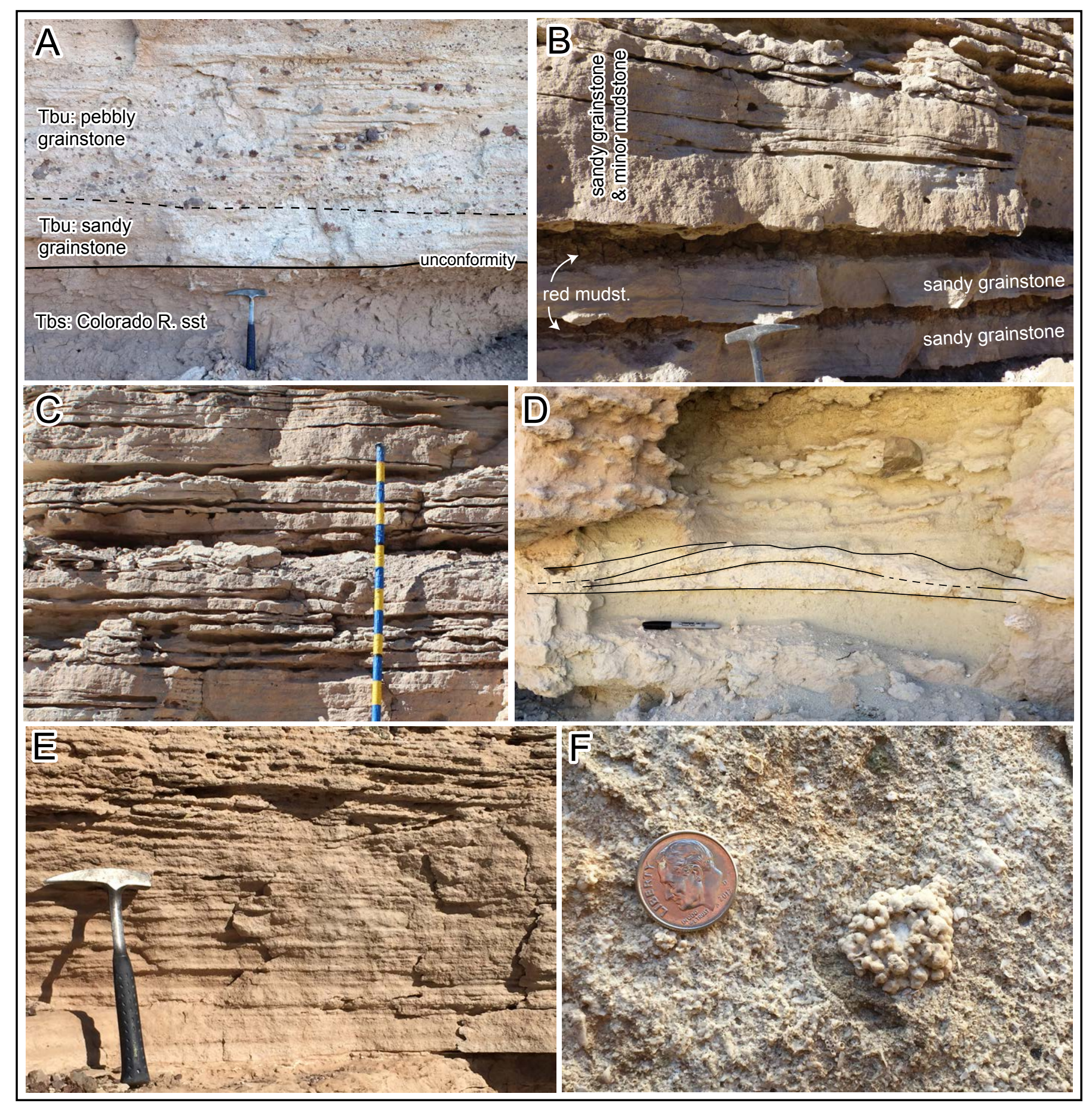

Figure 9. Field photos of facies association 1 (FA1): carbonate-rich bioclastic grainstone and minor red mudstone. A. Horizontally stratified sandy grainstone unconformably overlying Colorado River sandstone of the siliciclastic member (Tbs), overlain by FA2 pebbly grainstone. Locality KG12, southeast Palo Verde Mts (Figs. 5, 6). Hammer is $32.5 \mathrm{~cm}$ long. (B) Horizontally stratified and wave ripple-laminated sandy grainstone with thin beds of red mudstone. C. Well-sorted, thin-bedded ripple cross-laminated sandy grainstone alternating with thin to very thin red mudstone beds (recessive layers). Intervals on measuring stick are $10 \mathrm{~cm}$. D. Flat-based wave-formed ripple bedform in carbonate-rich bioclastic grainstone. Pen is $13.5 \mathrm{~cm}$ long. E. Very thin-bedded well sorted fine-grained grainstone and sandy grainstone; resistant white layers are nearly $100 \%$ carbonate (b/s ratio $>>1$ ) while darker recessive layers have $a \mathrm{~b} / \mathrm{s}$ ratio $\sim 1$. The high degree of compositional segregation, sorting, and planar bedding records traction transport and deposition by high-energy shallow-marine currents. F. Close-up view of well sorted fine-grained sandy bioclastic grainstone composed of barnacle and molluscan shell fragments, and a small clam shell heavily encrusted with small barnacles and coated with calcareous algae. Hammer is $32.5 \mathrm{~cm}$ long. 


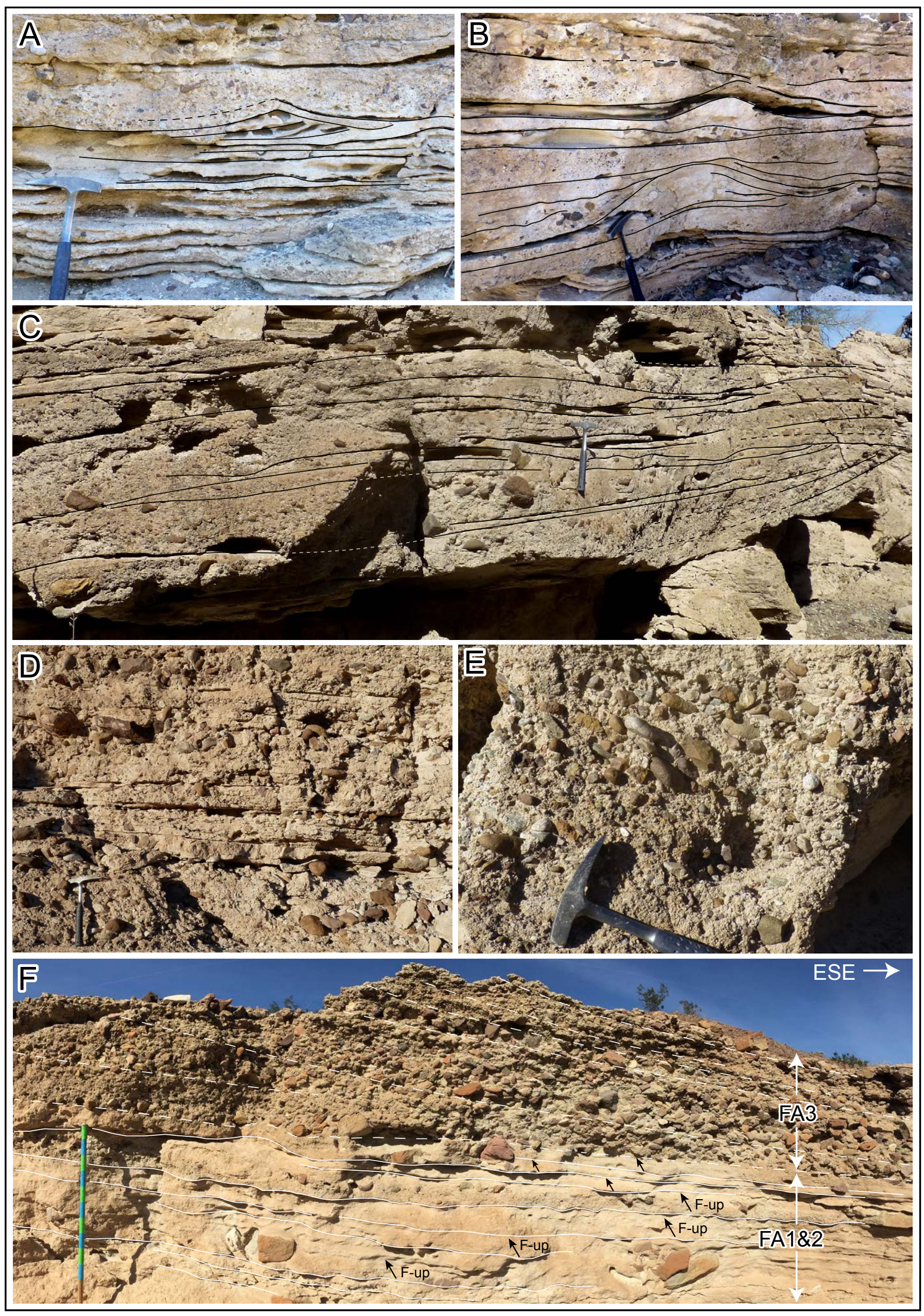

Figure 10. Caption in text. 


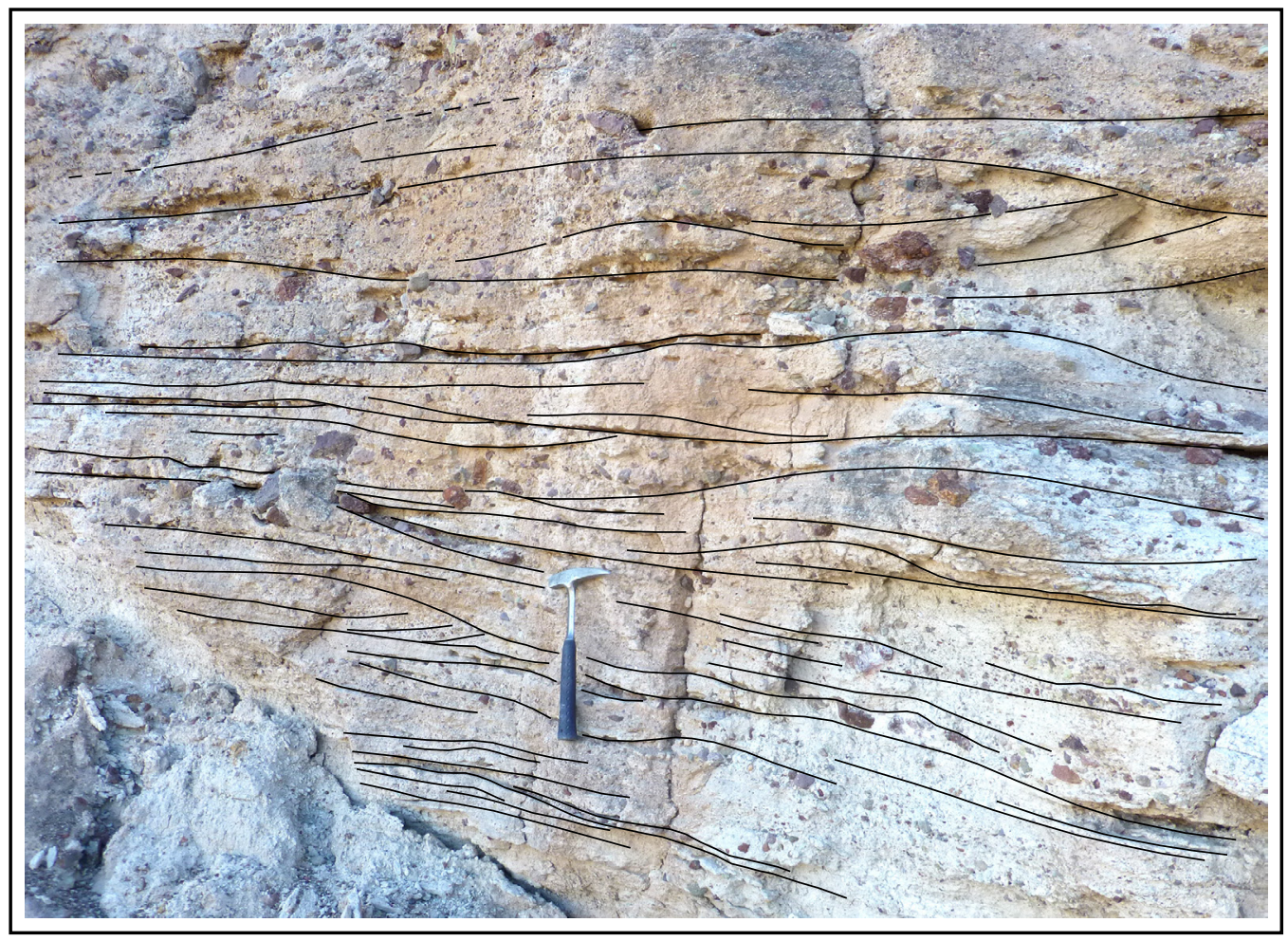

Figure 11. Detail of gravelly wave-formed ripple cross bedding in sandy and pebbly grainstone at site KG12 in the Palo Verde Mountains (Figs. 5, 8). Black lines highlight internal cross-bedding and external bounding surfaces that reveal a variety of diagnostic wave-formed ripple cross-bed geometries. Ripple bedform wavelengths in this exposure increase up-section from $\sim 0.25 \mathrm{~m}$ at the bottom to $\sim 2.6 \mathrm{~m}$ at the top, suggesting an increase in water depth during deposition of this interval. Hammer is $32.5 \mathrm{~cm}$ long. See text for discussion. 


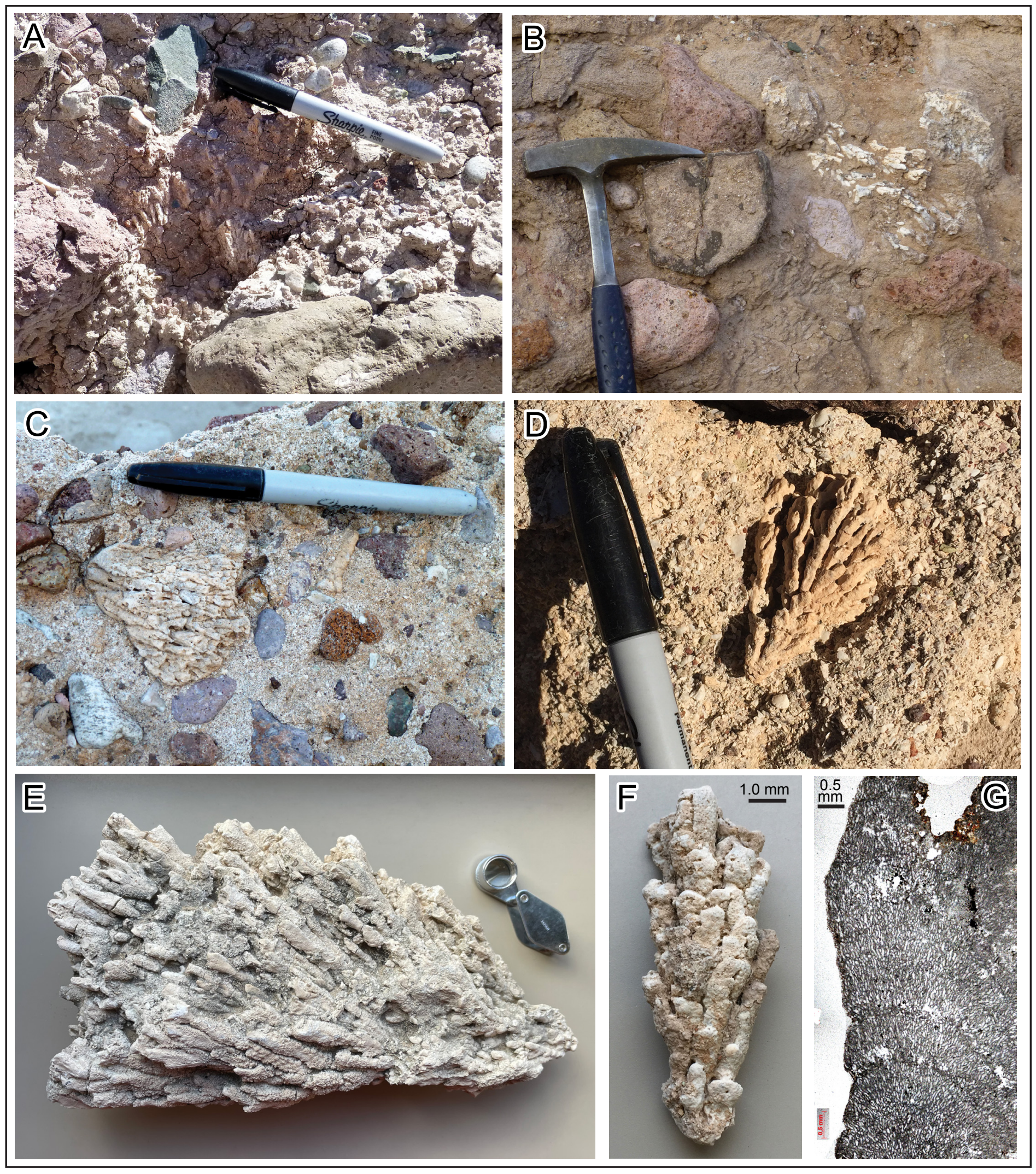

Figure 12. Coralline-like calcareous red algae in the upper bioclastic member. Caption in text. 


\section{A Section PVM-3}
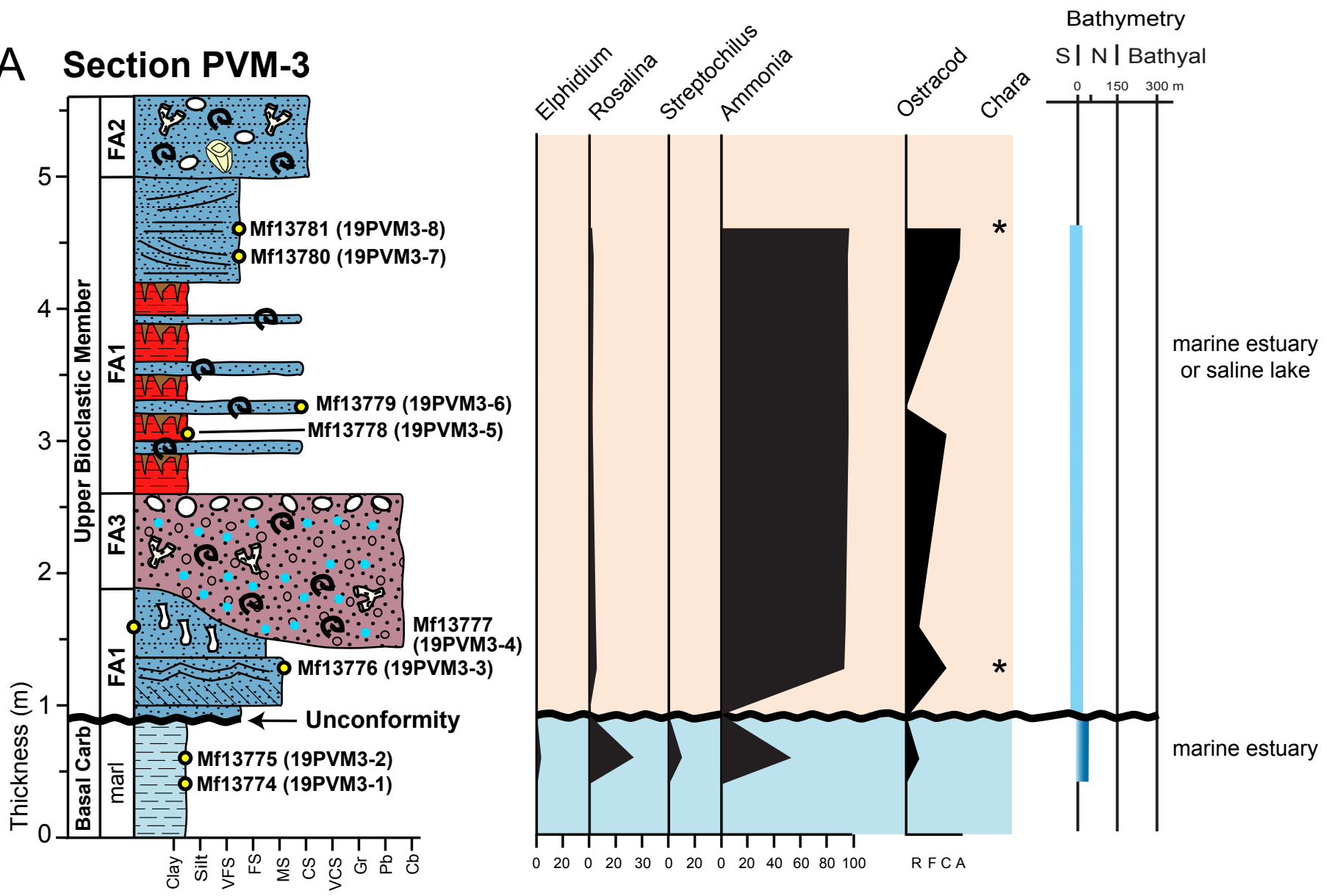

\section{B Section PVM-4}
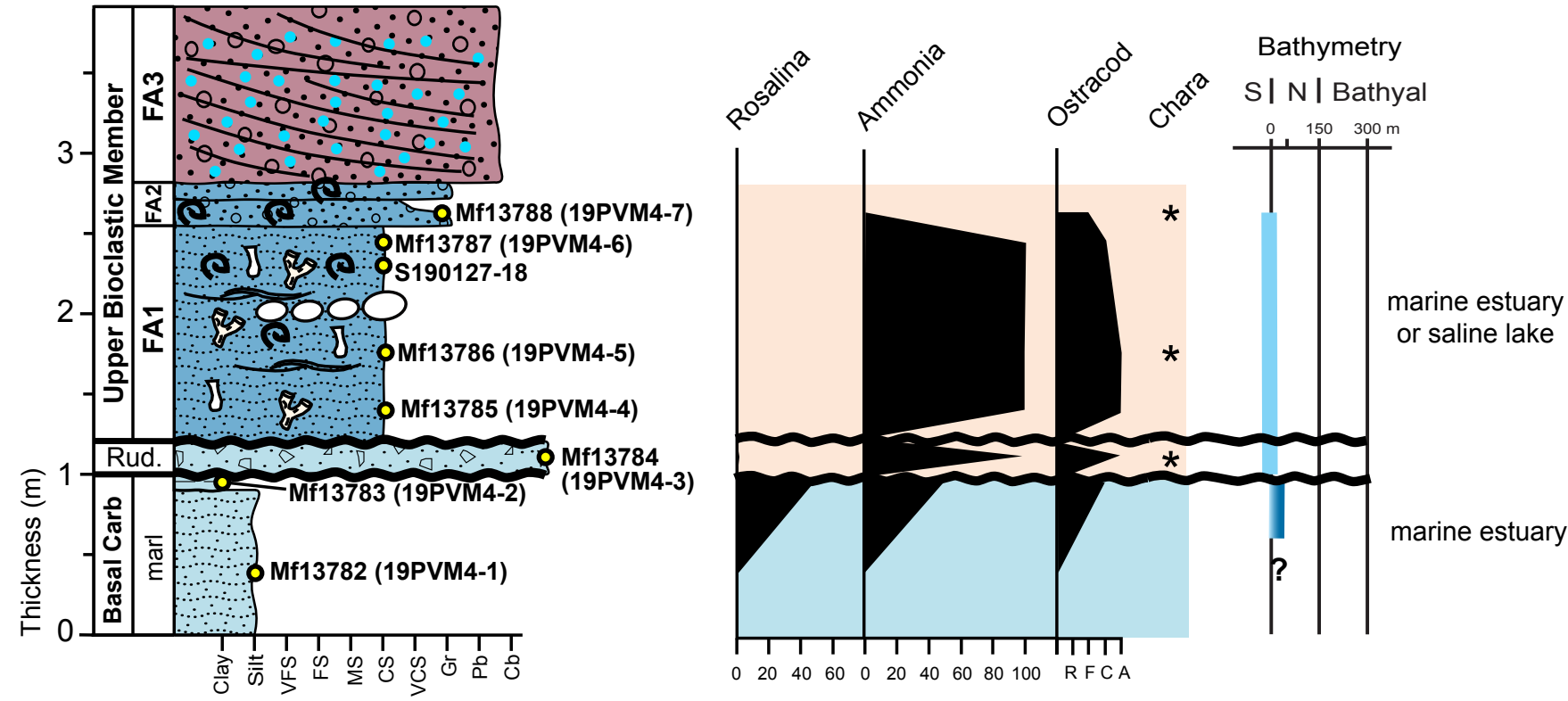

Figure 13. Two detailed measured sections through the upper bioclastic member in the Palo Verde Mountains, showing vertical arrangement of facies associations FA1 to FA3 and results of microfossil analysis. A. Section PVM-3. B. Section PVM-4. * indicates occurrence of Chara fragments. Locations shown in Fig. 5; data provided in Table S2. 


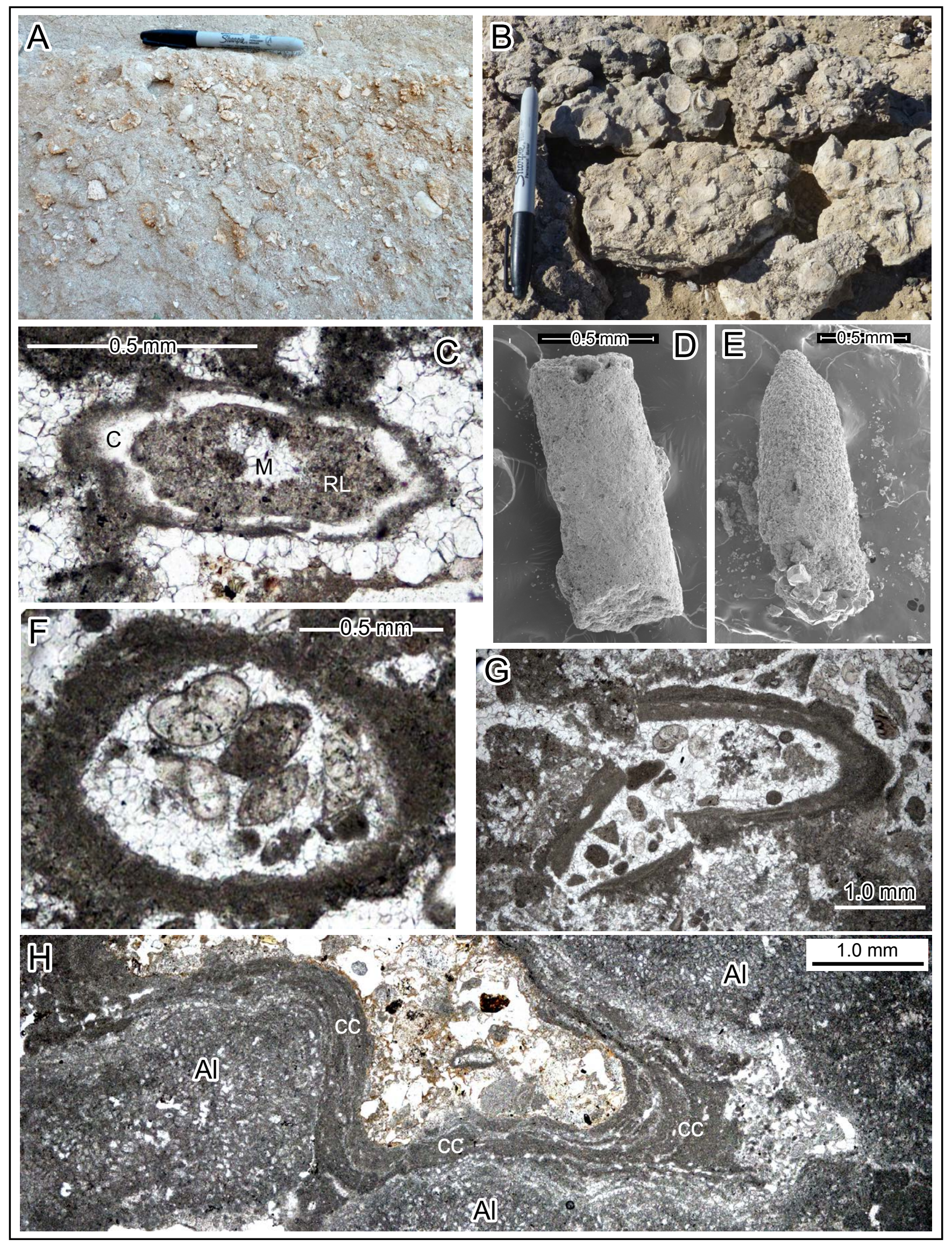

Figure 14. Caption in text. 

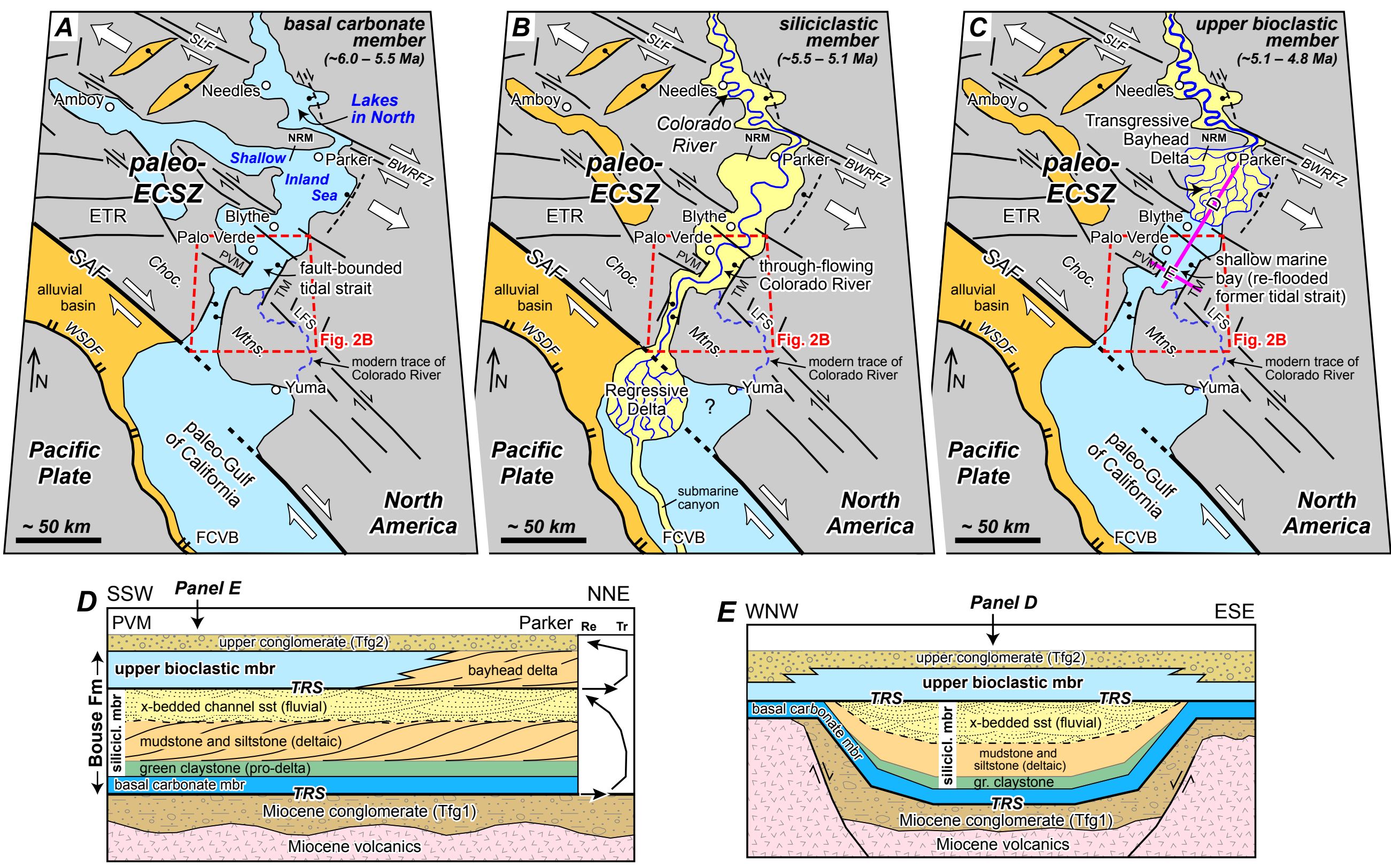

Figure 15. Oblique-perspective reconstructions of the lower Colorado River region during deposition of the three members of the Bouse Formation (see Dorsey et al., 2018 and 2021a, for details). (A) Basal carbonate member formed in a shallow inland sea and fault-bounded tidal strait at the north end of the paleo-Gulf of California, prior to arrival of the Colorado River. (B) The siliciclastic member records deposition in the earliest through-flowing Colorado River and delta system. The delta prograded rapidly south to the Salton Trough and delivered sand via turbidity currents to an offshore submarine canyon in the Fish Creek-Vallecito basin (FCVB). (C) The upper bioclastic member (this study) formed in a shallow marine bay located seaward of the backstepping Colorado River delta during regional transgression and re-flooding of the former tidal strait. Pink lines show position of transects in parts D and E. Map scale is approximate. See rest of caption in text. 